\title{
A Compilation of U.S. Geological Survey Pesticide Concentration Data for Water and Sediment in the Sacramento-San Joaquin Delta Region: 1990-2010
}

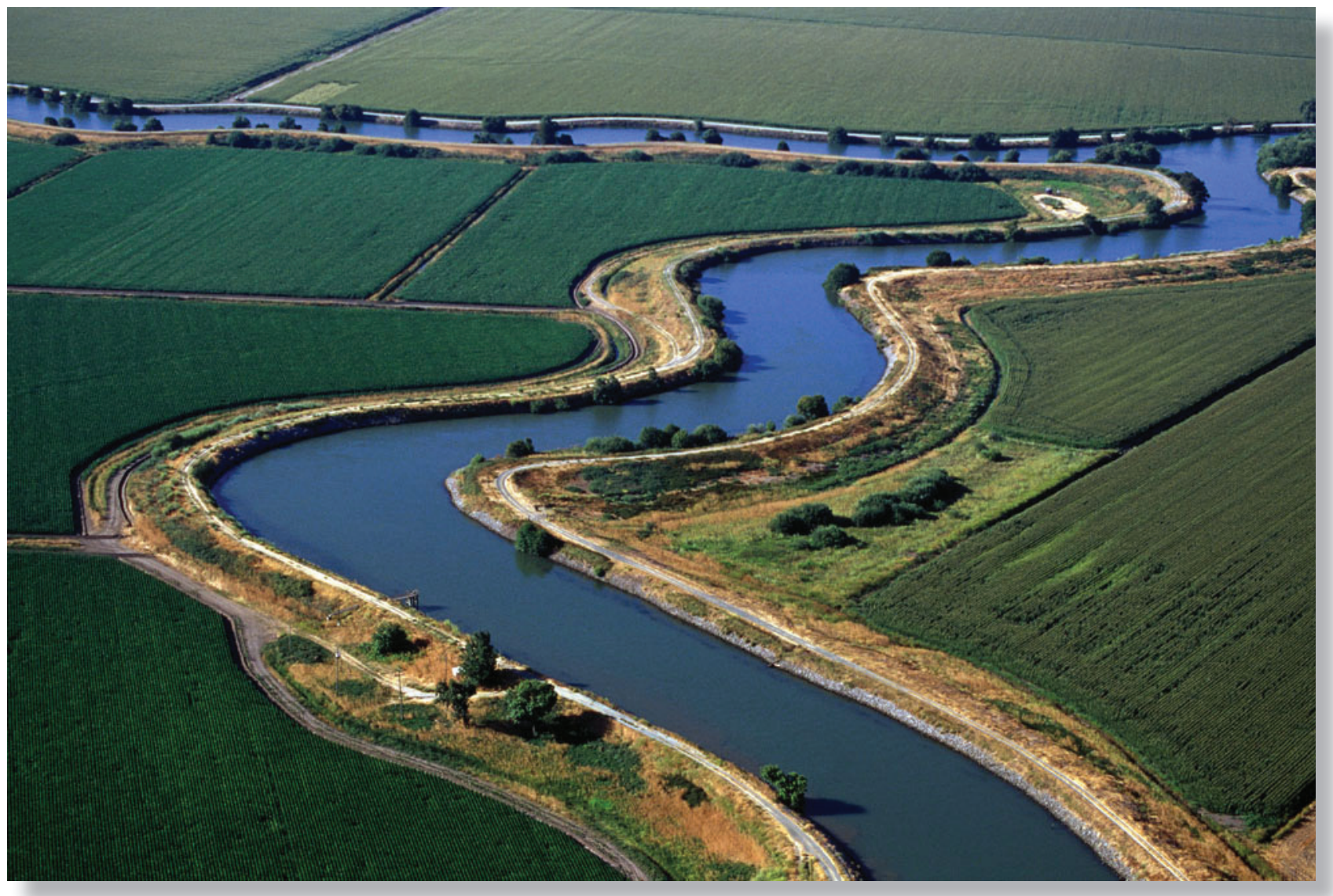

Data Series 756

U.S. Department of the Interior

U.S. Geological Survey 
Cover: View of the Sacramento-San Joaquin Delta region (photograph from California Department of Water Resources). 


\section{A Compilation of U.S. Geological Survey Pesticide Concentration Data for Water and Sediment in the Sacramento-San Joaquin Delta Region: 1990-2010}

By James L. Orlando

Data Series 756 


\section{U.S. Department of the Interior \\ KEN SALAZAR, Secretary}

\section{U.S. Geological Survey \\ Suzette M. Kimball, Acting Director}

U.S. Geological Survey, Reston, Virginia: 2013

For more information on the USGS — the Federal source for science about the Earth, its natural and living resources, natural hazards, and the environment, visit http://www.usgs.gov or call 1-888-ASK-USGS.

For an overview of USGS information products, including maps, imagery, and publications, visit http://www.usgs.gov/pubprod

To order this and other USGS information products, visit http://store.usgs.gov

Any use of trade, firm, or product names is for descriptive purposes only and does not imply endorsement by the U.S. Government.

Although this information product, for the most part, is in the public domain, it also may contain copyrighted materials as noted in the text. Permission to reproduce copyrighted items must be secured from the copyright owner.

Suggested citation:

Orlando, J.L., 2013, A compilation of U.S. Geological Survey pesticide concentration data for water and sediment in the Sacramento-San Joaquin Delta region: 1990-2010: U.S. Geological Survey Data Series 756, 46 p. 


\section{Contents}

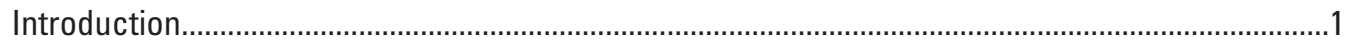

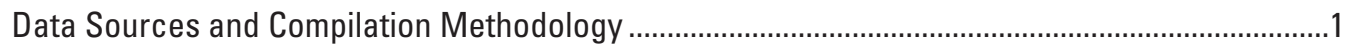

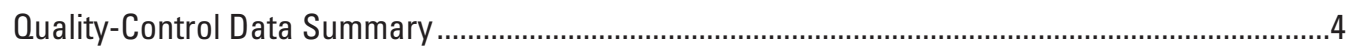

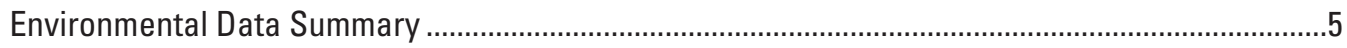

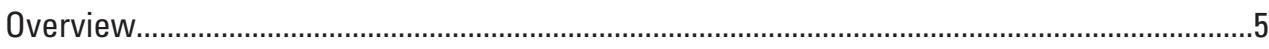

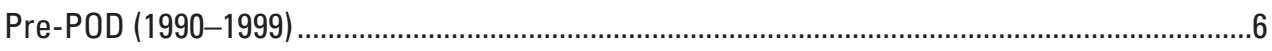

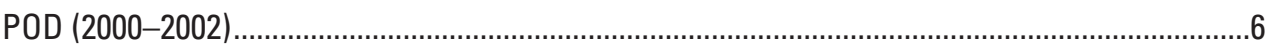

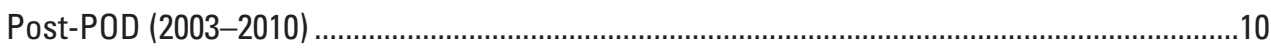

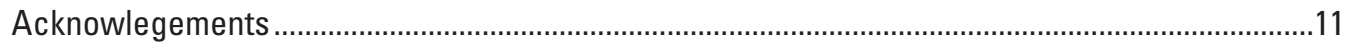

References Cited ................................................................................................................................. 11

Appendix 1. U.S. Geological Survey Pesticide Concentration Data for Environmental Water and Sediment Samples Collected at Surface-Water Sampling Sites in the Sacramento-San Joaquin Delta Region 1990-2010 ............................................................43

Appendix 2. U.S. Geological Survey Pesticide Concentration Data for Quality-Control Water and Sediment Samples Collected at Surface-Water Sampling Sites in the Sacramento-San Joaquin Delta Region 1990-2010 ..............................................................44

Appendix 3. References for Analytical Methods Applicable to Data Presented in

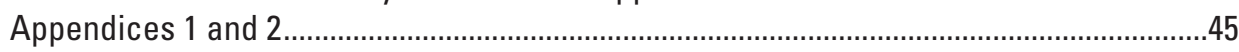




\section{Figures}

1. Map showing sampling locations and number of samples collected, Sacramento-San Joaquin Delta region,1990-2010.

2. Graph showing number of samples collected per year from the Sacramento-San Joaquin Delta region, 1990-2010

3. Graph showing number of sites sampled per year from the Sacramento-San Joaquin Delta region, 1990-2010.

4. Graph showing number of samples collected per season from the Sacramento-San Joaquin Delta region, 1990-2010

5. Map showing sampling locations and number of samples collected in the Sacramento-San Joaquin Delta region, 1990-1999

6. Map showing sampling locations and number of samples collected in the Sacramento-San Joaquin Delta region, 2000-2002

7. Map showing sampling locations and number of samples collected in the Sacramento-San Joaquin Delta region, 2003-2010

\section{Tables}

1. Publications associated with pesticide data retrieved from the U.S. Geological Survey National Water Information System database.

2. U.S. Geological Survey series reports from which pesticide concentration data were compiled.

3. U.S. Geological Survey sampling sites with pesticide data, and the number of samples collected in the Sacramento-San Joaquin Delta region for different types of samples, 1990-2010

4. Number of water samples analyzed and detections found by pesticide and period for the Sacramento-San Joaquin Delta region, 1990-2010.

5. Number of sediment samples analyzed and detections found by pesticide and period for the Sacramento-San Joaquin Delta region, 1990-2010

6. Number of samples by site analyzed for pesticides per year from 1990 to 2010 for the Sacramento-San Joaquin Delta region

7. Number of samples analyzed for pesticides per month from the Sacramento-San Joaquin Delta region from 1990 to 2010, by site 


\section{Conversion Factors}

\begin{tabular}{lcl}
\multicolumn{1}{c}{ SI to Inch/Pound } & & \\
\hline \multicolumn{1}{c}{ Multiply } & By & \multicolumn{1}{c}{ To obtain } \\
\hline centimeter $(\mathrm{cm})$ & Length & \\
millimeter $(\mathrm{mm})$ & 0.3937 & inch (in.) \\
meter $(\mathrm{m})$ & 0.03937 & inch (in.) \\
kilometer $(\mathrm{km})$ & 3.281 & foot (ft) \\
kilometer $(\mathrm{km})$ & 0.6214 & mile (mi) \\
meter $(\mathrm{m})$ & 0.5400 & mile, nautical (nmi) \\
\hline
\end{tabular}

Horizontal coordinate information is referenced to the North American Datum of 1983 (NAD 83)

Pesticide concentrations in water are given in micrograms per liter $(\mu \mathrm{g} / \mathrm{L})$ and nanograms per liter (ng/L). Pesticide concentrations is sediment are given in micrograms per kilogram ( $\mu \mathrm{g} / \mathrm{kg})$.

\section{Abbreviations}

$\begin{array}{ll}\text { MDL } & \text { method detection limit } \\ \text { NASQAN } & \text { National Stream Quality Accounting Network } \\ \text { NAWQA } & \text { National Water Quality Assessment Program } \\ \text { NWIS } & \text { USGS National Water Information System } \\ \text { NWQL } & \text { USGS National Water Quality Laboratory } \\ \text { POD } & \text { pelagic organism decline } \\ \text { QC } & \text { Quality-control } \\ \text { USGS } & \text { U.S. Geological Survey }\end{array}$




\title{
A Compilation of U.S. Geological Survey Pesticide Concentration Data for Water and Sediment in the Sacramento-San Joaquin Delta Region: 1990-2010
}

\author{
By James L. Orlando
}

\section{Introduction}

Beginning around 2000, abundance indices of four pelagic fishes (delta smelt, striped bass, longfin smelt, and threadfin shad) within the San Francisco Bay and Sacramento-San Joaquin Delta began to decline sharply (Sommer and others, 2007). These declines collectively became known as the pelagic organism decline (POD). No single cause has been linked to this decline, and current theories suggest that combinations of multiple stressors are likely to blame. Contaminants (including current-use pesticides) are one potential stressor being investigated for its role in the POD (Anderson, 2007). Pesticide concentration data collected by the U.S. Geological Survey (USGS) at multiple sites in the delta region over the past two decades are critical to understanding the potential effects of current-use pesticides on species of concern as well as the overall health of the delta ecosystem.

In April 2010, a compilation of contaminant data for the delta region was published by the State Water Resources Control Board (Johnson and others, 2010). Pesticide occurrence was the major focus of this report, which concluded that "there was insufficient high quality data available to make conclusions about the potential role of specific contaminants in the POD." The report cited multiple sources; however, data collected by the USGS were not included in the publication even though these data met all criteria listed for inclusion in the report.

What follows is a summary of publicly available USGS data for pesticide concentrations in surface water and sediments within the Sacramento-San Joaquin Delta region from the years 1990 through 2010. Data were retrieved though the USGS National Water Information System (NWIS) database, a publicly available online-data repository (U.S. Geological Survey, 1998), and from published USGS reports (also available online at http://pubs.er.usgs.gov/).

The majority of the data were collected in support of two long term USGS monitoring programs - National Water Quality Assessment Program (NAWQA; http://water.usgs.gov/ nawqa/) and National Stream Quality Accounting Network
(NASQAN; http://water.usgs.gov/nasqan/) — and through projects associated with the USGS Toxics Substances Hydrology Program (http://toxics.usgs.gov/). In addition, data were collected during multiple research projects that were supported by various federal, state, and local agencies.

Although these data have been previously published in some form, it is hoped that by focusing on samples collected within the delta region and presenting these data in a concise format, they will be a valuable resource for scientists, resource managers, and members of the public working to understand the role of pesticides in the POD and their potential effects on the overall health of the delta ecosystem.

\section{Data Sources and Compilation Methodology}

In an effort to facilitate comparisons to the data in Johnson and others (2010), similar sampling site and sampling date range criteria were used for the retrieval of pesticide data from the USGS NWIS database and published reports. Sampling sites were selected by creating a simple buffer of 30 miles around the legal delta boundary (fig. 1) by using ArcGIS (geographic information system) software (ESRI, Redlands, Calif.). A spatial dataset of all USGS surface-water sampling locations in the NWIS database was then overlain with the buffer, and all sites that fell within the buffer were selected (862 sites; fig. 1). A request was then submitted to the USGS California Water Science Center public information officer for all non-proprietary pesticide concentration data for water and sediment samples collected at these sites between January 1, 1990 and December 31, 2010. The NWIS data retrieval was completed on March 8, 2012, and represents all data meeting the previously described criteria present in the database at that time. All of the data have undergone review and approval and much of the data retrieved from NWIS have been previously published in USGS reports or scientific journals. Table 1 lists a number of these publications, which can be consulted for additional project specific details. 


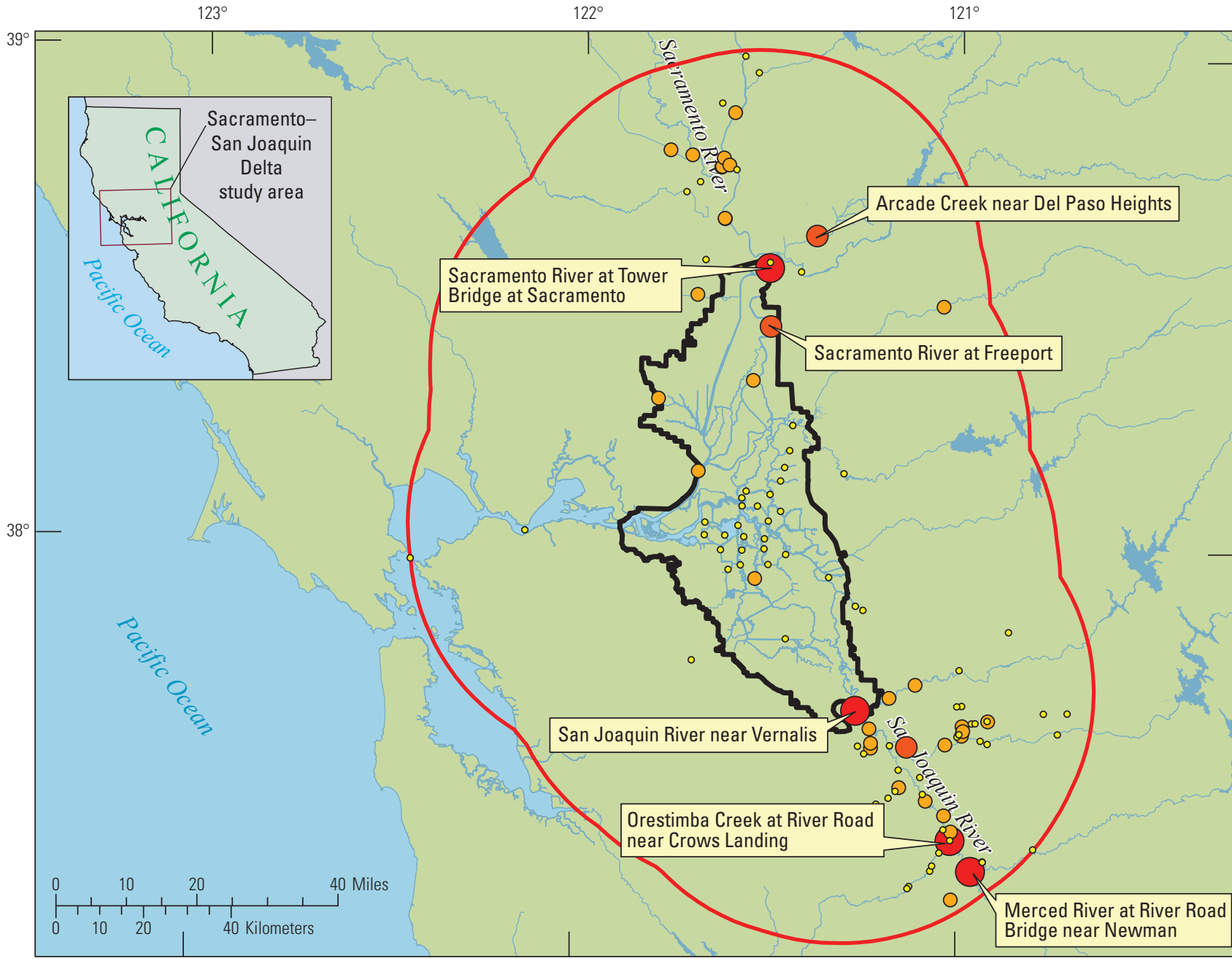

\section{EXPLANATION}

\begin{tabular}{|lll}
\hline 30-mile buffer & Number of samples analyzed \\
\hline Legal delta boundary & $\circ$ & Less than 10 \\
& $\bigcirc$ & 10 to 100 \\
& $\bigcirc$ & 101 to 250 \\
& Greater than 250
\end{tabular}

Figure 1. Sampling locations and number of samples collected, Sacramento-San Joaquin Delta region,1990-2010. 
Table 1. Publications associated with pesticide data retrieved from the U.S. Geological Survey National Water Information System database.

\section{References}

Brown, L.R., Panshin, S.Y., Kratzer, C.R., Zamora, Celia, and Gronberg, J.M., 2004, Occurrence, distribution, instantaneous loads, and yields of dissolved pesticides in the San Joaquin River Basin, California, during summer conditions, 1994 and 2001: U.S. Geological Survey Scientific Investigations Report 2004-5083, 61 p.

Dileanis, P.D., Bennett, K.P., and Domagalski, J.L., 2002, Occurrence and transport of diazinon in the Sacramento River, California, and selected tributaries during three winter storms, January-February 2000: U.S. Geological Survey Water-Resources Investigations Report 2002-4101, 78 p.

Domagalski, J.L., 1996, Occurrence of dicofol in the San Joaquin River, California: Bulletin of Environmental Contamination and Toxicology, v. 57, no. 2 .

Domagalski, J.L., 1996, Pesticides and pesticide degradation products in stormwater runoff: Sacramento River Basin, California: J.American Water Resources Assoc, v. 32, no. 5.

Domagalski, J.L., 1997, Pesticides in surface and ground water of the San Joaquin-Tulare Basins, California: Analysis of available data, 1966 through 1992: U.S. Geological Survey Water Supply Paper 2468, 74 p.

Domagalski, J.L., 2000, Pesticides in surface water measured at select sites in the Sacramento River Basin, California, 1996-1998: U.S. Geological Survey Water-Resources Investigations Report 2000-4203, 24 p.

Domagalski, J.L, and Dileanis, P.D., 2000, Water-quality assessment of the Sacramento River Basin, California: Water quality of fixed sites, 1996-1998: U.S. Geological Survey Water-Resources Investigations Report 2000-4247, 60 p.

Domagalski, J.L., and Kuivila, K.M., 1991, Transport and transformation of dissolved rice pesticides in the Sacramento River Delta, California: U.S. Geological Survey Open-File Report 91-227, 5 p.

Domagalski, J.L., and Munday, C., 2003, Evaluation of diazinon and chlorpyrifos concentrations and loads, and other pesticide concentrations, at selected sites in the San Joaquin Valley, California, April to August, 2001: U.S. Geological Survey Water-Resources Investigations Report 2003-4088, 60 p.

Domagalski, J.L., Dubrovsky, N.M., and Kratzer, C.R., 1997, Organic chemicals in the environment: Pesticides in the San Joaquin River, California: Inputs from dormant sprayed orchards: Journal of Environmental Quality, v. 26, no. 2, p. 454-465.

Domagalski, J.L., Knifong, D.L., MacCoy, D.E., Dileanis, P.D, Dawson, B.J., and Majewski, M.S., 1998, Water quality assessment of the Sacramento River Basin, California-Environmental setting and study design: U.S. Geological Survey Water-Resources Investigations Report 97-4254, 31 p.

Domagalski, J.L., Dileanis, P.D., Knifong, D.L., Munday, C.M., May, J.T., Dawson, B.J., Shelton, J.L., and Alpers, C.N., 2000, Water-quality assessment of the Sacramento River Basin, California, Water-quality, sediment and tissue chemistry, and biological data, 1995-1998: U.S. Geological Survey Open-File Report 2000-391.

Domagalski, J.L., Knifong, D.L., Dileanis, P.D., Brown, L.R., May, J.T., Connor, V., and Alpers, C.N., 2000, Water quality in the Sacramento River Basin, California, 1994-98: U.S. Geological Survey Circular 1215, 36 p.

Domagalski, J.L., Weston, D.P., Zhang, M., and Hladik, M., 2010, Pyrethroid insecticide concentrations and toxicity in streambed sediments and loads in surface waters of the San Joaquin Valley, California, USA: Environmental Toxicology and Chemistry, v. 29, no. 4, p. 813-823.

Dubrovsky, N.M., Kratzer, C.R., Brown, L.R., Gronberg, J.M., and Burow, K.R., 1998, Water quality in the San Joaquin-Tulare Basins, California, 1992-95: U.S. Geological Survey Circular 1159, 38 p.

Dubrovsky, N.M., Kratzer, C.R., Panshin, S.Y., Gronberg, J.A.M., and Kuivila, K.M., 2000, Pesticide transport in the San Joaquin River Basin: ACS Symposium Series, v. 751.

Hladik, M.L., Domagalski, J.L., and Kuivila, K.M., 2009, Concentrations and loads of suspended sediment-associated pesticides in the San Joaquin River, California and tributaries during storm events: Science of the Total Environment, v. 408, p. 356-364.

Kratzer, C.R., 1997, Transport of diazinon in the San Joaquin River Basin, California: U.S. Geological Survey Open-File Report 97-411, 17 p.

Kratzer, C.R., 1998, Pesticides in storm runoff from agricultural and urban areas in the Tuolumne River Basin in the vicinity of Modesto, California:

U.S. Geological Survey Water-Resources Investigations Report 98-4017, 17 p.

Kratzer, C.R., 1998, Transport of sediment-bound organochlorine pesticides to the San Joaquin River, California: U.S. Geological Survey Open-File Report 97-655, 30 p.

Kratzer, C.R., 1999, Transport of diazinon in the San Joaquin River Basin, California: Journal of the American Water Resources Association, v. 35, no. 2 , p. 379-395.

Kratzer, C.R., Zamora, C., and Knifong, D.L., 2002, Diazinon and chlorpyrifos loads in the San Joaquin River Basin, California, January and February 2000: U.S. Geological Survey Water-Resources Investigations Report 2002-4103, 45 p.

MacCoy, D.E., and Domagalski, J.L., 1999, Trace elements and organic compounds in streambed sediment and aquatic biota from the Sacramento River Basin, California, October and November 1995: U.S. Geological Survey Water-Resources Investigations Report 99-4151, 37 p.

Munday, Cathy, and Domagalski, J.L., 2003, Quality-control results for ground-water and surface-water data, Sacramento River Basin, California, National Water-Quality Assessment, 1996-1998: U.S. Geological Survey Water-Resources Investigations Report 2002-4201, 54 p.

Panshin, S., Dubrovsky, N.M., Gronberg, J.M., and Domagalski, J.L., 1998, Occurrence and distribution of dissolved pesticides in the San Joaquin River Basin, California: U.S. Geological Survey Water-Resources Investigations Report 98-4032, 88 p.

Pereira, W.E., Domagalski, J.L., Hostettler, F.D., Brown, L.R., and Rapp, J.B., 1996, Occurrence and accumulation of pesticides and organic contaminants in river sediment, water and clam tissues from the San Joaquin River and tributaries, California: Environmental Toxicology and Chemistry, v. 15 , no. 2 , p. $172-180$.

Zamora, Celia, Kratzer, C.R., Majewski, M.S., and Knifong, D.L., 2003, Diazinon and chlorpyrifos loads in precipitation and urban and agricultural storm runoff during January and February 2001 in the San Joaquin River Basin, California: U.S. Geological Survey Water-Resources Investigations Report 2003-4091, 56 p. 
USGS pesticide concentration data meeting the previously described criteria, but not in the NWIS database, were also compiled for this report. These data were published and described in detail in six USGS reports shown in table 2. These data were formatted to match the data retrieved from the NWIS database and are presented along with those data in appendix 1. Selected quality-control data associated with these environmental data are presented in appendix 2. As in Johnson and others (2010), the data presented in this report are briefly described for three periods; pre-POD (1990-1999), POD (2000-2002), and post-POD (2003-2010).

Some of the results in appendices 1 and 2 are reported as less than some numerical value. For data retrieved from the NWIS database, these numerical values represent a mixture of method detection limits and minimum reporting levels that are dependent on when the sample was analyzed because reporting procedures and analytical methods at the USGS National Water Quality Laboratory (NWQL) evolved over time. Details of how these values were determined are reported in two publications: National Water Quality Laboratory Technical Memorandum 1994-12 (U.S. Geological Survey, 1994) and Childress and others (1999). Additional details of reporting procedures used by the NWQL can be found in Maloney (2005), the individual analytical method reports cited in appendix 3 , and at http://nwql.usgs.gov/Public/techmemo.shtml.

Data in appendix 1 that were derived from the USGS reports referenced in table 1 are also frequently reported as less than some numerical value. In the original reports, these data were reported as non-detections, but to correspond with the data retrieved from NWIS, these data were assigned numerical values that represent the method detection limits determined for their respective projects. For the purposes of this report, all data shown as less than some numerical value are considered to be non-detections when determining the number of detections for a particular pesticide.

Data produced by the NWQL and reported in appendices 1 and 2 with an "E" qualifier, meaning "estimated or having a higher degree of uncertainty" represent detections of an analyte at concentrations below the method detection limit (MDL); between the long-term MDL and the laboratory reporting level; or, in rare cases, greatly elevated concentrations that exceed the calibration standards of the analytical instrument (National Water Quality Laboratory Technical Memorandum 1994-12 and Childress and others, 1999). Data produced by the Organic Chemistry Research Laboratory are reported with an "E" qualifier if the result was below the MDL determined during the specific project described in the reports referenced in table 1. Estimated data from these sources $(7,370$ results) are, for the purposes of this report, considered to be confirmed detections of a particular pesticide; however, these data should be used with the understanding that their uncertainty is greater than that of data reported without an "E" remark code.

\section{Quality-Control Data Summary}

Two USGS laboratories, the NWQL located in Lakewood, Colo., and the Organic Chemistry Research Laboratory located in Sacramento, Calif., were responsible for the majority of analyses presented in this report. Each laboratory adheres to rigorous quality-control protocols. Documents describing the protocols followed at the NWQL, along with descriptions of analytical methods, are available at http://nwql.usgs.gov/nwql.shtml, and specific analytical method references are in appendix 3. Quality-control (QC) data and detailed descriptions of the analytical methods used by the Sacramento laboratory are presented in the reports cited in table 1. Lastly, prior to release to the public through the NWIS database or through published reports, all data were subject to multiple levels of review to ensure the quality of the data.

Three types of QC data were retrieved from the NWIS database: field blanks, field replicates, and fieldspike samples. A total of 406 QC samples were retrieved (398 surface-water QC samples and 8 sediment QC samples), representing 37 sites over the 1990-2010 period. Out of the 406 samples, there were 130 field blanks, 161 field-replicates, and 115 field-spike samples. These data are presented in appendix 2.

Field blanks are collected to test the effectiveness of equipment cleaning procedures and to assess contamination due to field and laboratory handling of the sample. In brief, of the 130 field blanks retrieved from NWIS (127 water and 3 sediment), 20 water samples had detections of at least one pesticide (including "E" values). There were a total of 15 detections of a pesticide above its MDL in 6 of these samples, with 1 sample (site 11274538 collected on August 8, 1992) accounting for 9 detections. Only two samples (site 11273500 collected on January 12, 2000, and site 11303500 collected on June 21, 2001) had pesticide detections greater than 10 times the respective MDLs of the pesticides present (diazinon and chlorpyrifos in the former sample and simazine in the latter). All other results were non-detections.

Field replicates are collected to assess variability for a given sample matrix and to test the reproducibility of results for a set of laboratory procedures. Listed in appendix 2 are 161 field-replicate samples (156 water and 5 sediment samples) with 9,149 environmental sample and replicate sample analyte pairs. These included 1,166 paired detections of a pesticide in both the environmental sample and its replicate (including estimated values), with relative standard deviations ranging from 0 to 123 percent. Fifty analyte pairs exceeded a relative standard deviation of 25 percent, although thirteen of these exceedances were due to one sample pair (site 11274538, collected on June 17, 1992). Of the 1,166 paired detections, there were 372 instances in which both the environmental and 
Table 2. U.S. Geological Survey series reports from which pesticide concentration data were compiled.

\begin{tabular}{|c|c|c|}
\hline Data source & Publication reference & Publication URL \\
\hline 1 & $\begin{array}{l}\text { Smalling, K.L., Orlando, J.L., and Kuivila, K.M., 2005, Analysis of pesticides } \\
\text { in surface water and sediment from Yolo Bypass, California, 2004-2005: } \\
\text { U.S. Geological Survey Scientific Investigations Report 2005-5220, } 20 \text { p. }\end{array}$ & http://pubs.usgs.gov/sir/2005/5220/ \\
\hline 2 & $\begin{array}{l}\text { Orlando, J.L., and Kuivila, K.M., 2004, Changes in rice pesticide use and } \\
\text { surface water concentrations in the Sacramento River watershed, California: } \\
\text { U.S. Geological Survey Scientific Investigations Report 2004-5097, } 28 \text { p. }\end{array}$ & http://pubs.usgs.gov/sir/2004/5097/ \\
\hline 4 & $\begin{array}{l}\text { Orlando, J.L., Kuivila, K.M., and Whitehead, A., 2003, Dissolved pesticide } \\
\text { concentrations detected in storm-water runoff at selected sites in the } \\
\text { San Joaquin River Basin, California, 2000-2001: U.S. Geological Survey } \\
\text { Open-File Report 03-0101, } 16 \text { p. }\end{array}$ & http://pubs.usgs.gov/of/2003/ofr03101/ \\
\hline 6 & $\begin{array}{l}\text { MacCoy, D., Crepeau, K.L., and Kuivila, K.M., 1995, Dissolved pesticide data } \\
\text { for the San Joaquin River at Vernalis and the Sacramento River at Sacramento, } \\
\text { California, 1991-94: U.S. Geological Survey Open-File Report 95-110, } 27 \text { p. }\end{array}$ & http://pubs.usgs.gov/of/1995/0110/report.pdf \\
\hline
\end{tabular}

replicate values were estimates. In these cases, the uncertainty associated with the "E" values is likely similar to the differences between the replicate values, and therefore, these pairs had acceptable agreement and relative standard deviations were not determined. There were an additional 192 instances of a detection of an analyte in either the replicate sample or the environmental sample where there was no corresponding detection in the other sample (including estimated values). In only 39 of these instances did the detection exceed 1.5 times the analyte's MDL, and no particular sample or analyte accounted for a substantial portion of these unpaired detections. Finally, there were 7,791 instances in which both the environmental and replicate samples were reported as nondetections, which was considered acceptable agreement.

Field-spike samples are used to assess analyte recovery, degradation, sorption, and interferences caused by the sampling matrix. These data are presented in appendix 2 for 115 water samples collected at 21 sites as total concentrations (spike concentration plus environmental concentration). For information on spiking levels, the reader can consult the method references listed in appendix 2 .

Quality-control data contained within the USGS reports listed in table 1 fully met the data-quality objectives of the studies described in the respective reports. As a result, all the environmental data in these reports were deemed satisfactory and are included in appendix 1. Each report contains a detailed written description of the quality-assurance procedures followed and QC data produced for that study, which can be used as a reference. Quality-control data for these studies are not included in appendix 2.

\section{Environmental Data Summary}

\section{Overview}

From 1990 to 2010, a total of 3,370 (3,249 water and 121 sediment), samples were collected at 113 surface-water sites in the delta region and analyzed for pesticides by USGS laboratories (fig. 1 and table 3, at back of report). During this period, 276 pesticides and pesticide degradates were analyzed in water samples and 127 were analyzed in sediments, although not all pesticides were analyzed in every sample because analytical methods changed over time. These analyses yielded a total of 155,340 individual pesticide concentration results $(152,703$ results for water samples and 2,637 results for sediment samples), including "E" values and "less than" results as described earlier.

Overall, 124 pesticides were detected in water and 37 in sediments (including "E" values). Herbicides were the most commonly analyzed and detected type of pesticide in water samples, and a variety of chemical classes were represented. Insecticides were the most common type of pesticide analyzed and detected in sediment samples, and these were primarily organochlorines and pyrethroids (tables 4 and 5, at back of report). The majority of the samples $(2,187)$ were collected at six sites: Arcade Creek near Del Paso Heights, Merced River at River Road Bridge near Newman, Orestimba Creek at River Road near Crows Landing, Sacramento River at Freeport, Sacramento River at Tower Bridge at Sacramento, and San Joaquin River near Vernalis) (fig. 1 and table 2). Table 6 (at back of report) lists the number 
of samples analyzed for pesticides for each sampling site per year from 1990 to 2010 . The total number of samples collected per year was large in the early 1990s, then decreased until 1999, but peaked in 2001 preceding a general decline (fig. 2). The number of sites sampled per year peaked in 1994-95 (fig. 3). Seasonally, the greatest number of samples was collected during the winter (December-February), and the least in the fall (September-November), as shown in table 7 (at back of report) and figure 4.

\section{Pre-POD (1990-1999)}

During the pre-POD years, a total of 1,566 samples were collected from 81 surface-water sites within 30 miles of the delta and analyzed by USGS laboratories for pesticides. Of these, 1,520 were water samples and 46 were sediment samples. During this period, water samples were analyzed for 112 pesticides and degradates, and sediment samples were analyzed for 42 , although not every sample was analyzed for all of the compounds. During this period, 65 pesticides were detected in water and 25 were detected in sediment. Details on the types and classes of pesticides analyzed and detected in the water and sediment samples can be found in tables 4 and 5, respectively. Samples were collected from sites within the delta as well as from tributaries to the delta. Approximately 70 percent of the samples were collected from four sites: the Merced River at River Road Bridge near Newman, Orestimba Creek at River Road near Crows Landing, Sacramento River at Tower Bridge at Sacramento, and San Joaquin River near Vernalis (fig. 5).

\section{POD (2000-2002)}

During the POD years, a total of 1,200 samples were collected from 40 surface-water sites and analyzed by USGS laboratories for pesticides. No sediment samples were collected during this time. During this period, water samples were analyzed for 194 unique pesticides and degradates, although not every compound was analyzed for in every sample. Overall, 91 pesticides were detected. Details on the types and classes of pesticides analyzed and detected can be found in table 4 (at back of report). Samples generally were collected from sites outside the legal boundary of the delta, with the majority of samples collected from the San Joaquin River or its tributaries (fig. 6).

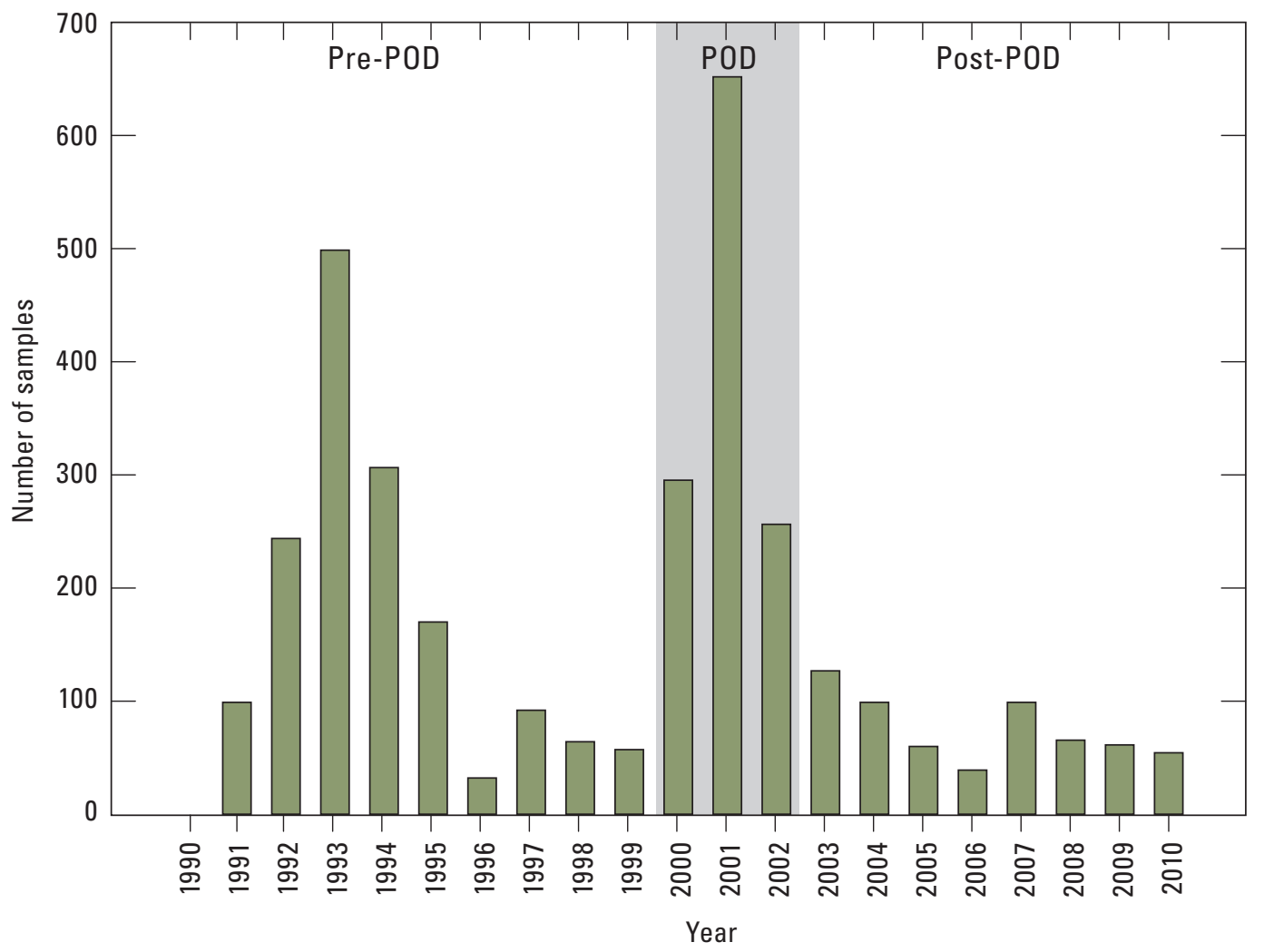

Figure 2. Number of samples collected per year from the Sacramento-San Joaquin Delta region, 1990-2010. 


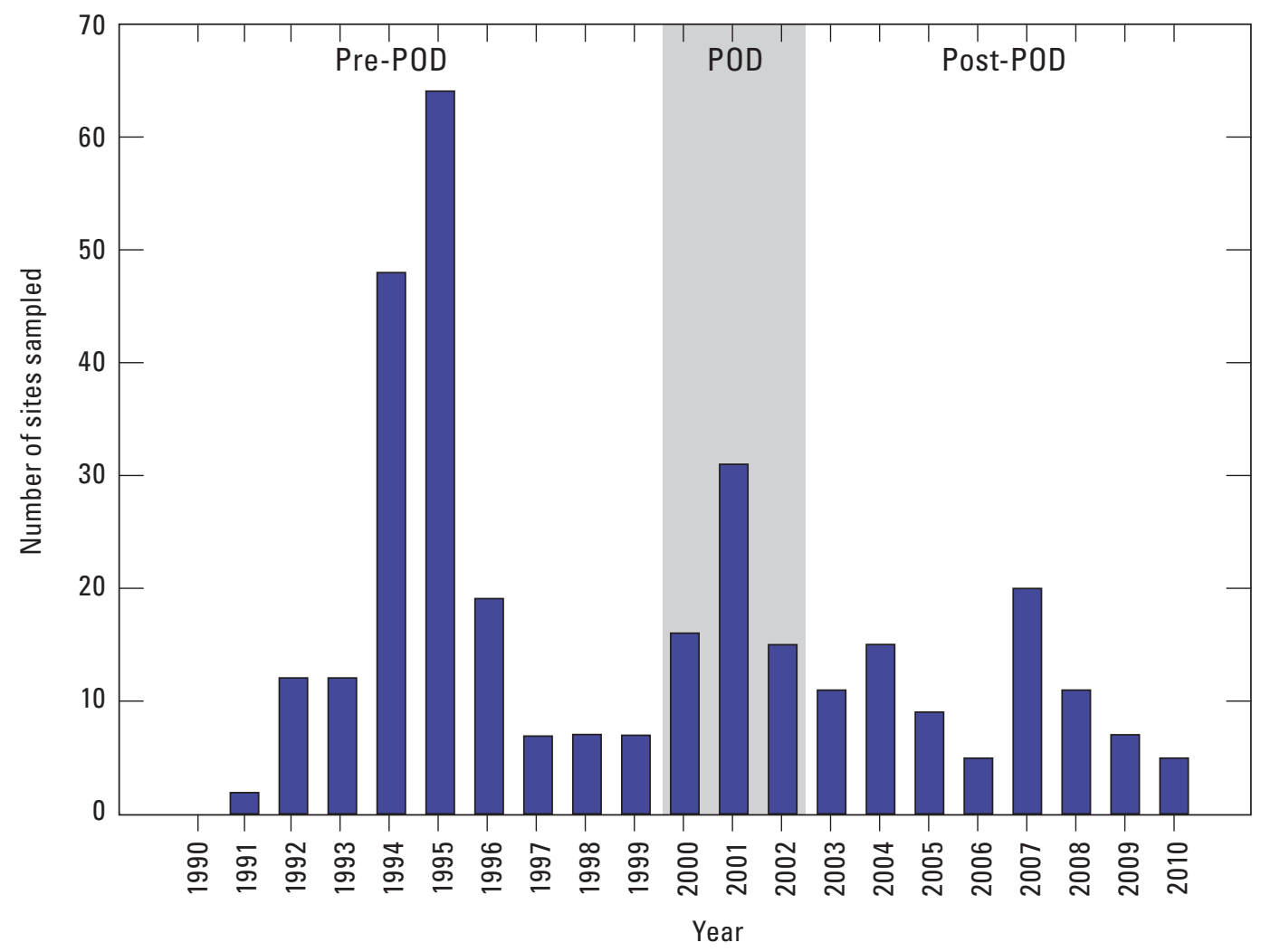

Figure 3. Number of sites sampled per year from the Sacramento-San Joaquin Delta region, 1990-2010.

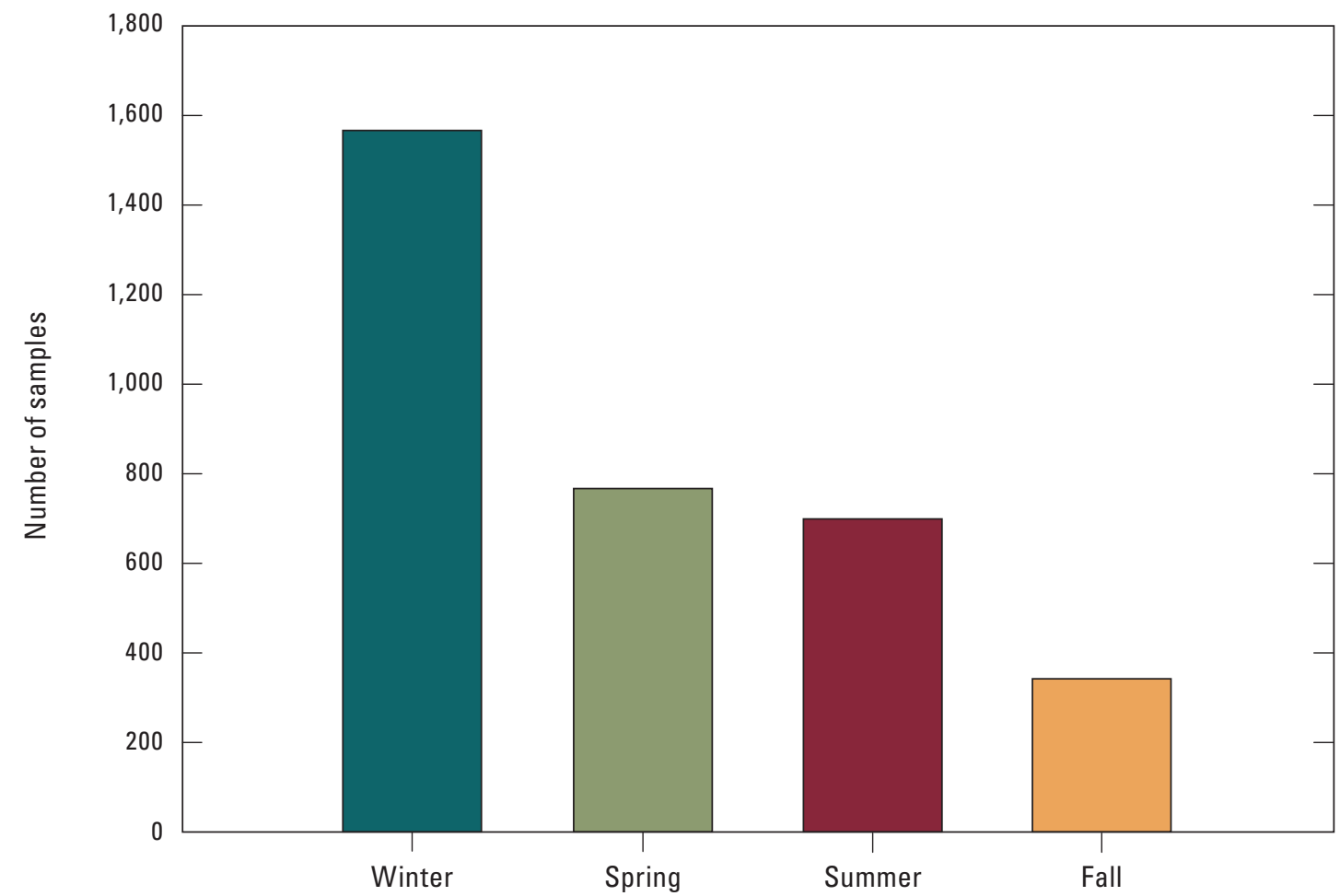

Figure 4. Number of samples collected per season from the Sacramento-San Joaquin Delta region, 1990-2010. 


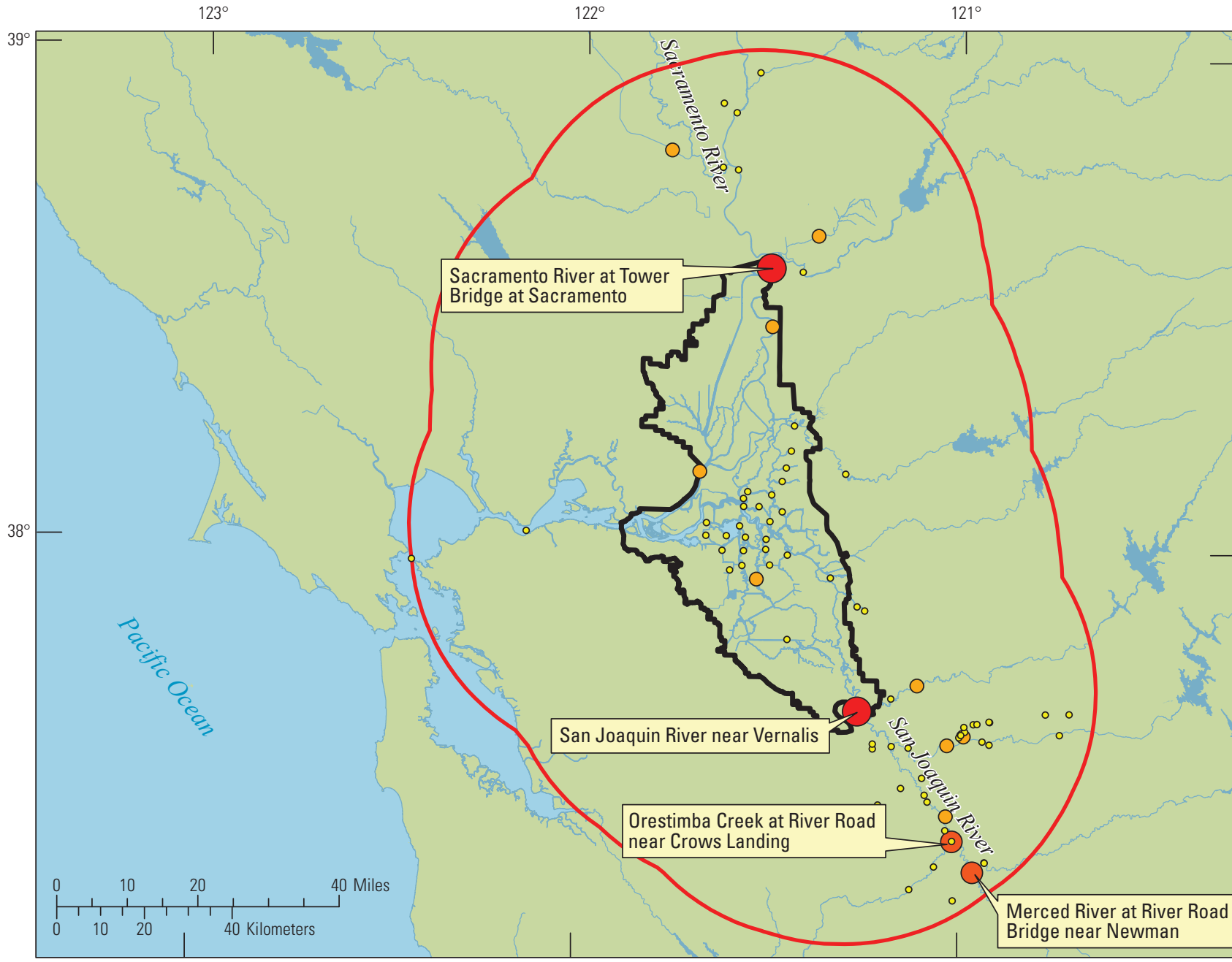

\section{EXPLANATION}

1990-1999

30-mile buffer

Number of samples analyzed

Legal delta boundary

- Less than 10

○ 10 to 100

C 101 to 250

Greater than 250

Figure 5. Sampling locations and number of samples collected in the Sacramento-San Joaquin Delta region, 1990-1999. 

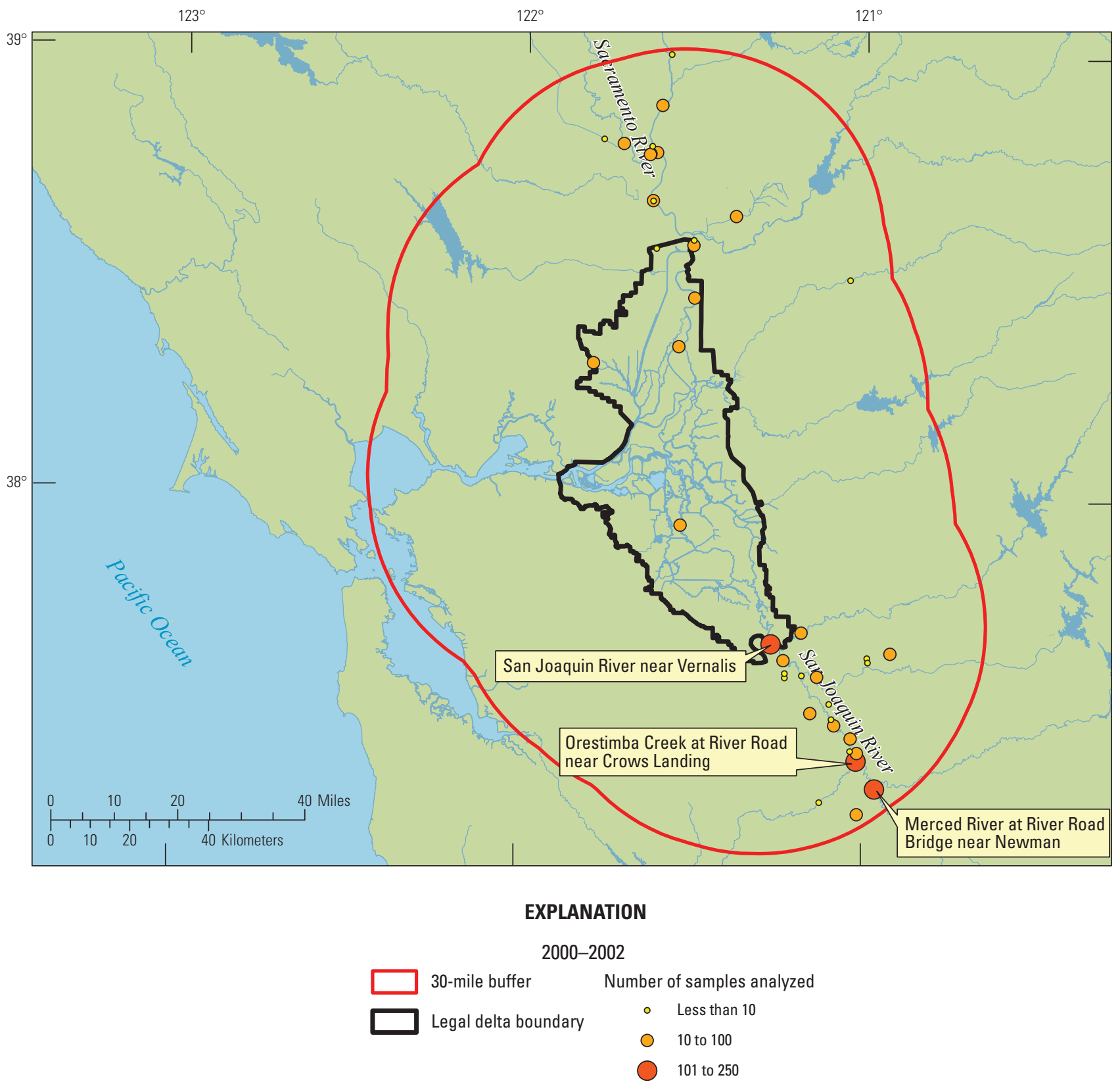

Figure 6. Sampling locations and number of samples collected in the Sacramento-San Joaquin Delta region, 2000-2002. 


\section{Post-POD (2003-2010)}

During the post-POD years, a total of 604 samples were collected from 39 surface-water sites and analyzed by USGS laboratories for pesticides. Of these, 529 were water samples and 75 were sediment samples. During this period, 257 pesticides and degradates were analyzed in water samples, and 107 were analyzed in sediment samples, although not all of the compounds were analyzed in every sample. Overall, 92 pesticides were detected in water and 13 in sediment. Details on the types and classes of pesticides analyzed and detected in the water and sediment samples can be found in tables 4 and 5, respectively. During this period, the majority of samples were collected at two sites representing the two major inputs to the delta: Sacramento River at Freeport and San Joaquin River near Vernalis (fig. 7).

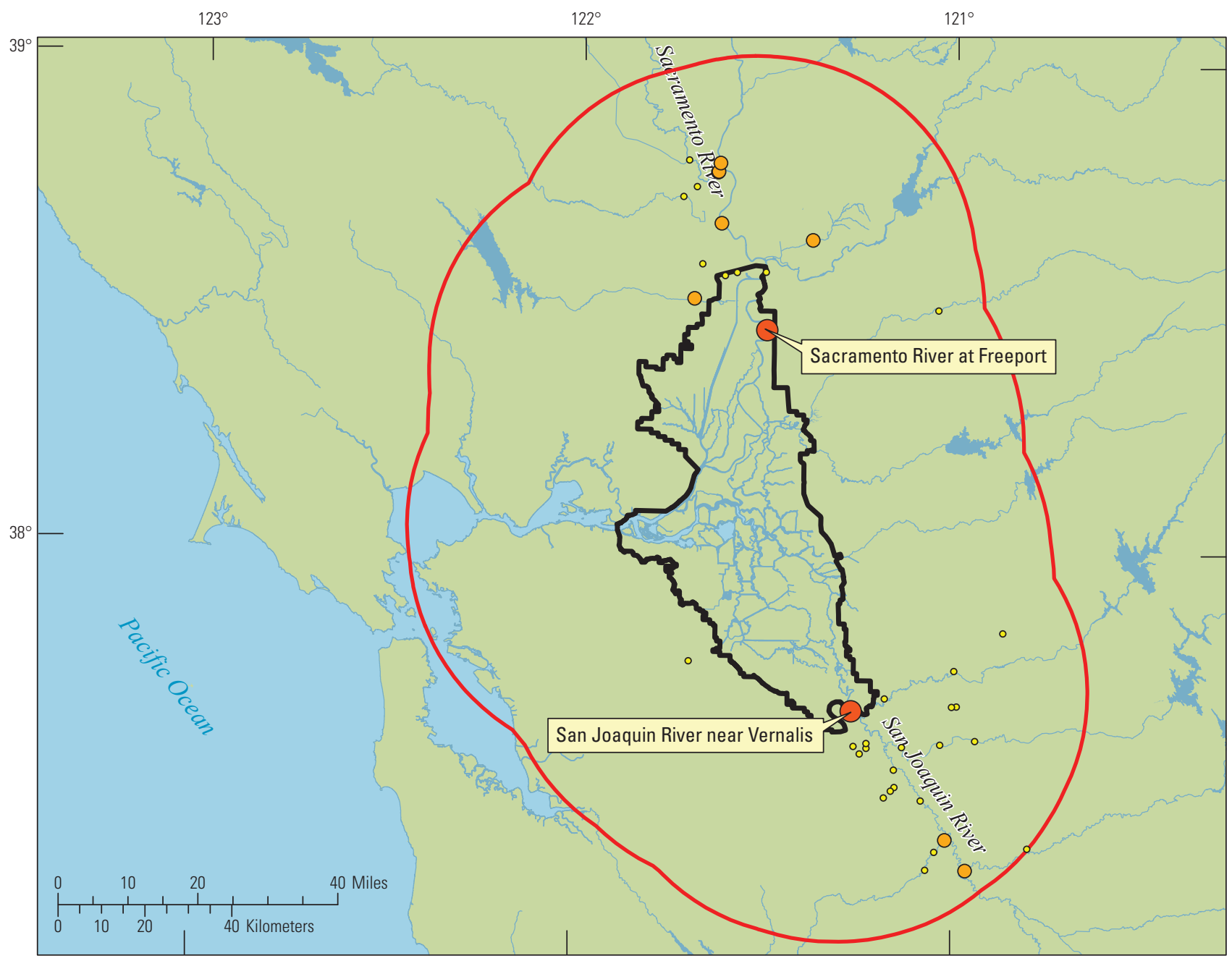

\section{EXPLANATION}

\begin{tabular}{|lrl} 
& $2003-2010$ \\
\hline 30 -mile buffer & Number of samples analyzed \\
\hline Legal delta boundary & $\circ$ & Less than 10 \\
& $\bigcirc$ & 10 to 100 \\
& 101 to 250
\end{tabular}

Figure 7. Sampling locations and number of samples collected in the Sacramento-San Joaquin Delta region, 2003-2010. 


\section{Acknowledgements}

This report was funded by the U.S. Geological Survey California Water Science Center Research Program.

\section{References Cited}

Anderson, S, 2007, Biomarkers and the Pelagic Organism Decline, Conclusions of the POD Biomarker Task Force: Fort Mason, San Francisco, August 29-30, 2007.

Childress, C.J.O., Foreman, W.T., Connor, B.F., and Maloney, T.J., 1999, New reporting procedures based on longterm method detection levels and some considerations for interpretations of water-quality data provided by the U.S. Geological Survey National Water Quality Laboratory: U.S. Geological Survey Open File Report 99-193, 19 p.

Johnson, M.L., Werner, I, Teh, S, and Loge, F, 2010, Evaluation of Chemical Toxicological, and Histopathologic Data to Determine their Role in the Pelagic Organism Decline: Central Valley Regional Water Quality Control Board, Rancho Cordova, Calif. Available online at http://www. swrcb.ca.gov/rwqcb5/water_issues/delta_water_quality/ comprehensive_monitoring_program/contaminant_ synthesis_report.pdf

Maloney, T.J., ed., 2005, Quality management system, U.S. Geological Survey National Water Quality Laboratory: U.S. Geological Survey Open-File Report 2005-1263, version $1.3,9$ November 2005, chapters and appendices variously paged.

Sommer, T., Armor, C., Baxter, R., Breuer, R., Brown, L., Chotkowski, M., Culberson, S., Feyrer, F., Gingras, M., Herbold, B., Kimmerer, W., Mueller-Solger, A., Nobriga, M., Souza, K., 2007, The Collapse of Pelagic Fishes in the Upper San Francisco Estuary: American Fisheries Society, v. 32, no, 6, p. 270-277

U.S. Geological Survey, 1994, Description and guide for interpreting low-level data supplied by the NWQL for schedules 2001, 2010, 2050, and 2051: U.S. Geological Survey National Water Quality Laboratory Technical Memorandum 94.12, accessed May 25, 2012, available at URL http:// nwql.usgs.gov/Public/techmemo.shtml

U.S. Geological Survey, 1998, National Water Information System (NWIS): U.S. Geological Survey Fact Sheet FS-027-98, accessed September 24, 2012, available at URL http://pubs.usgs.gov/fs/FS-027-98/fs-027-98.pdf 


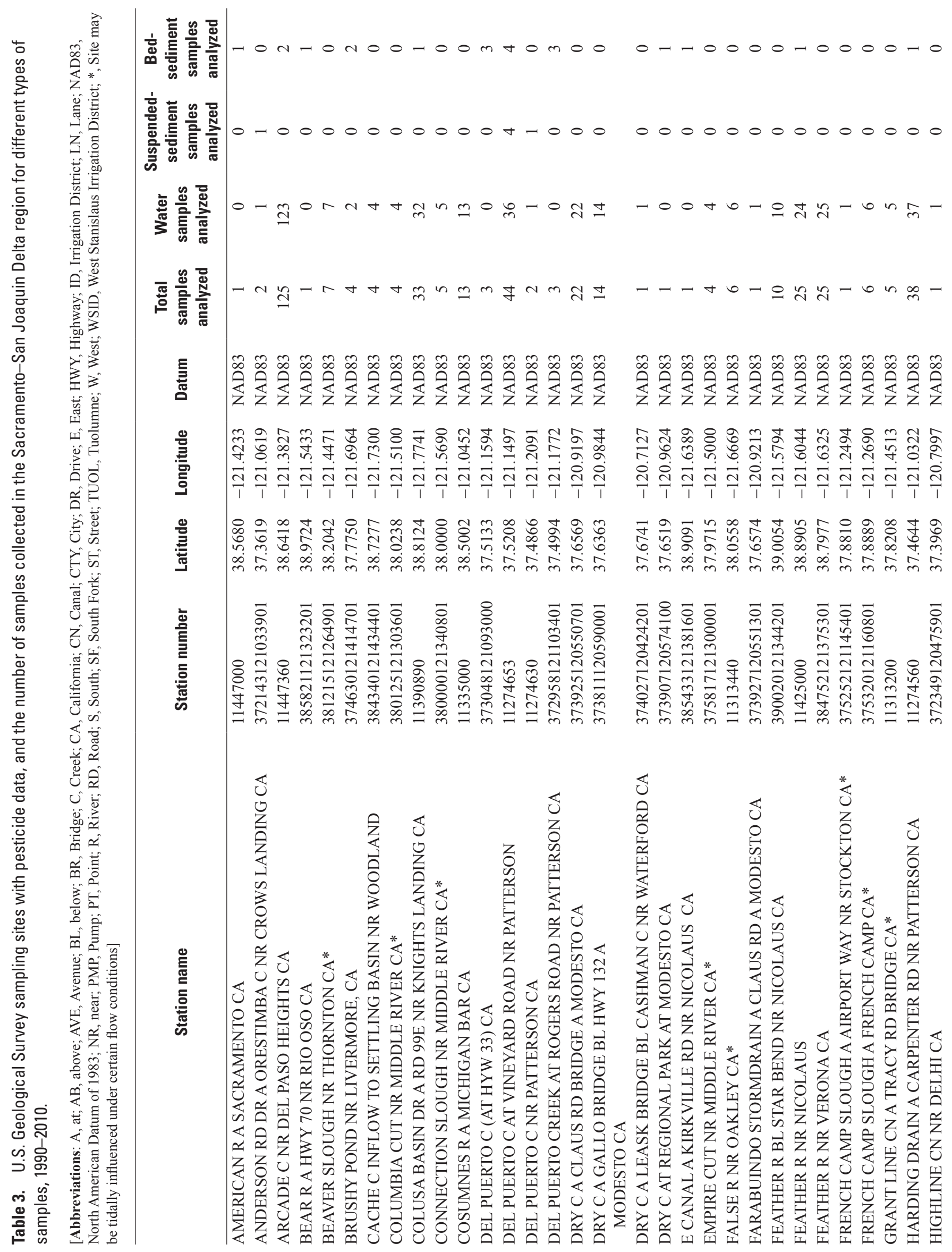




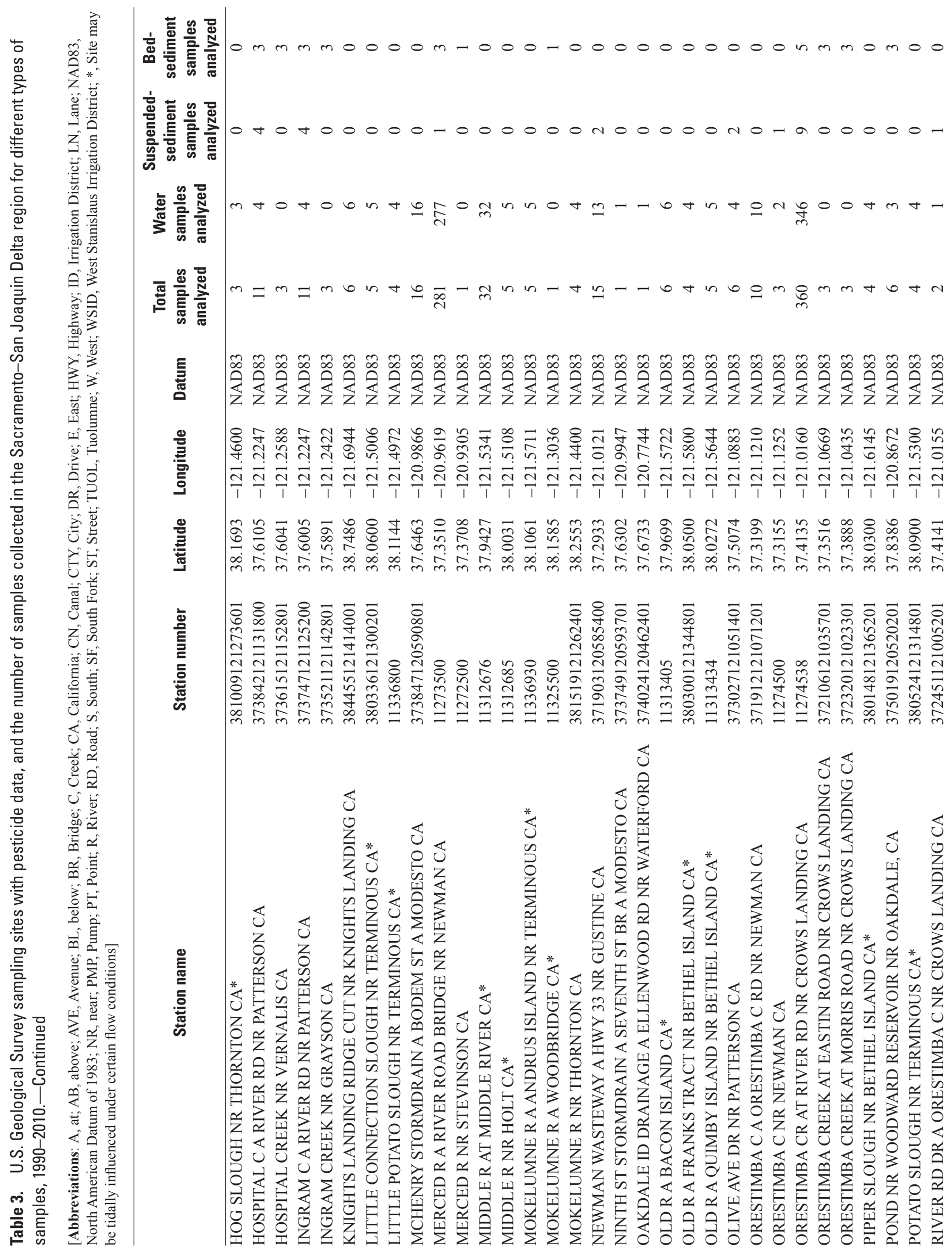




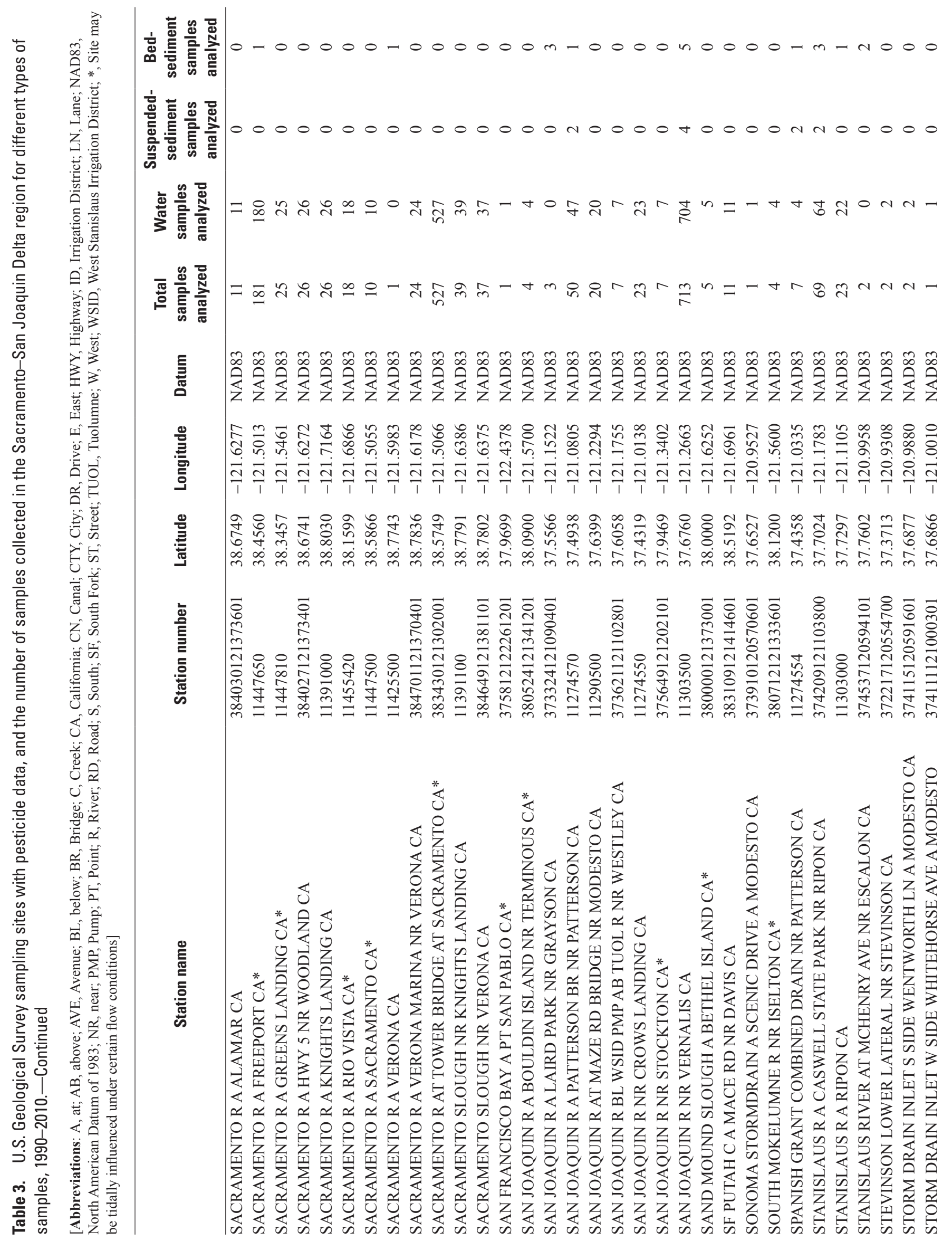




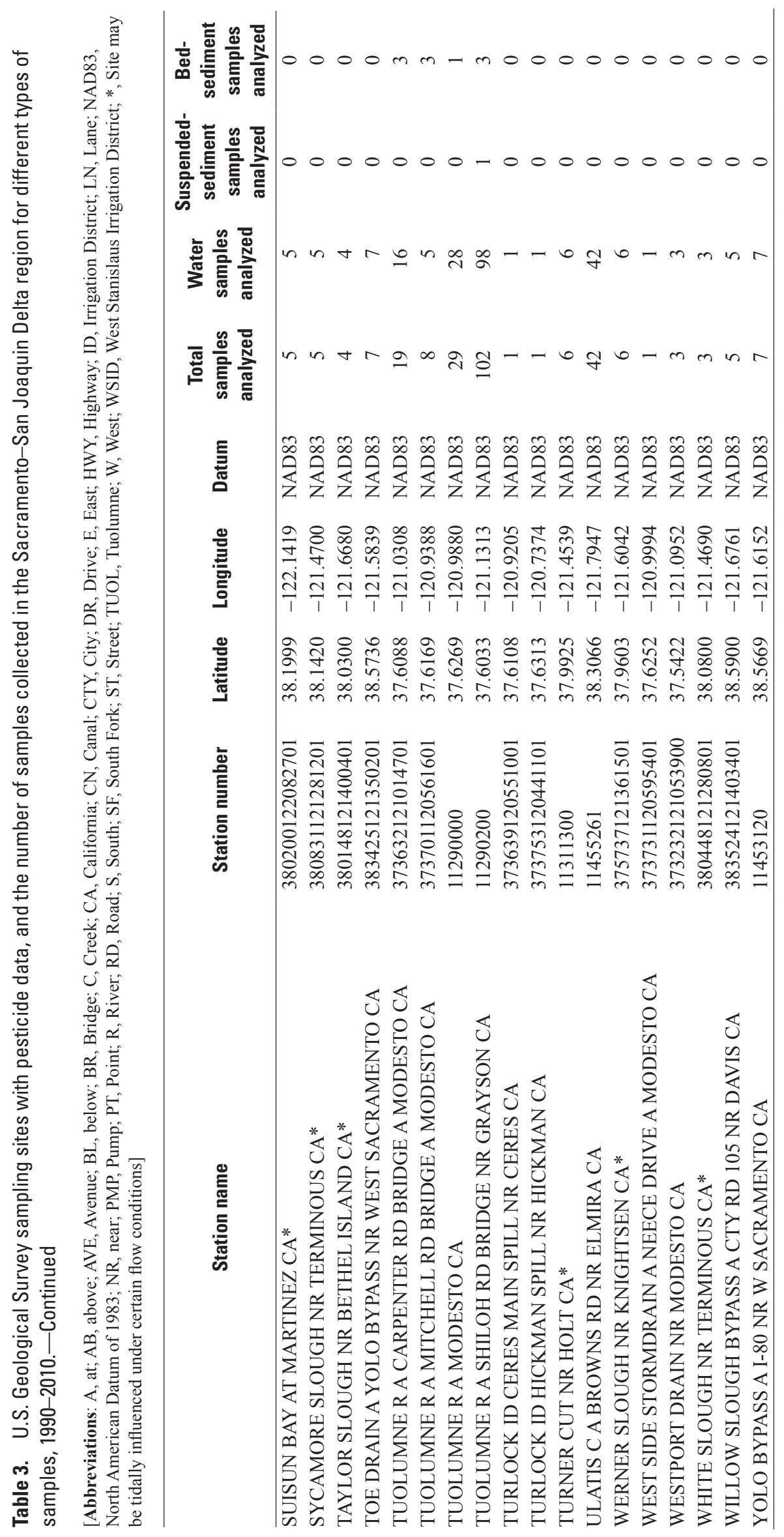




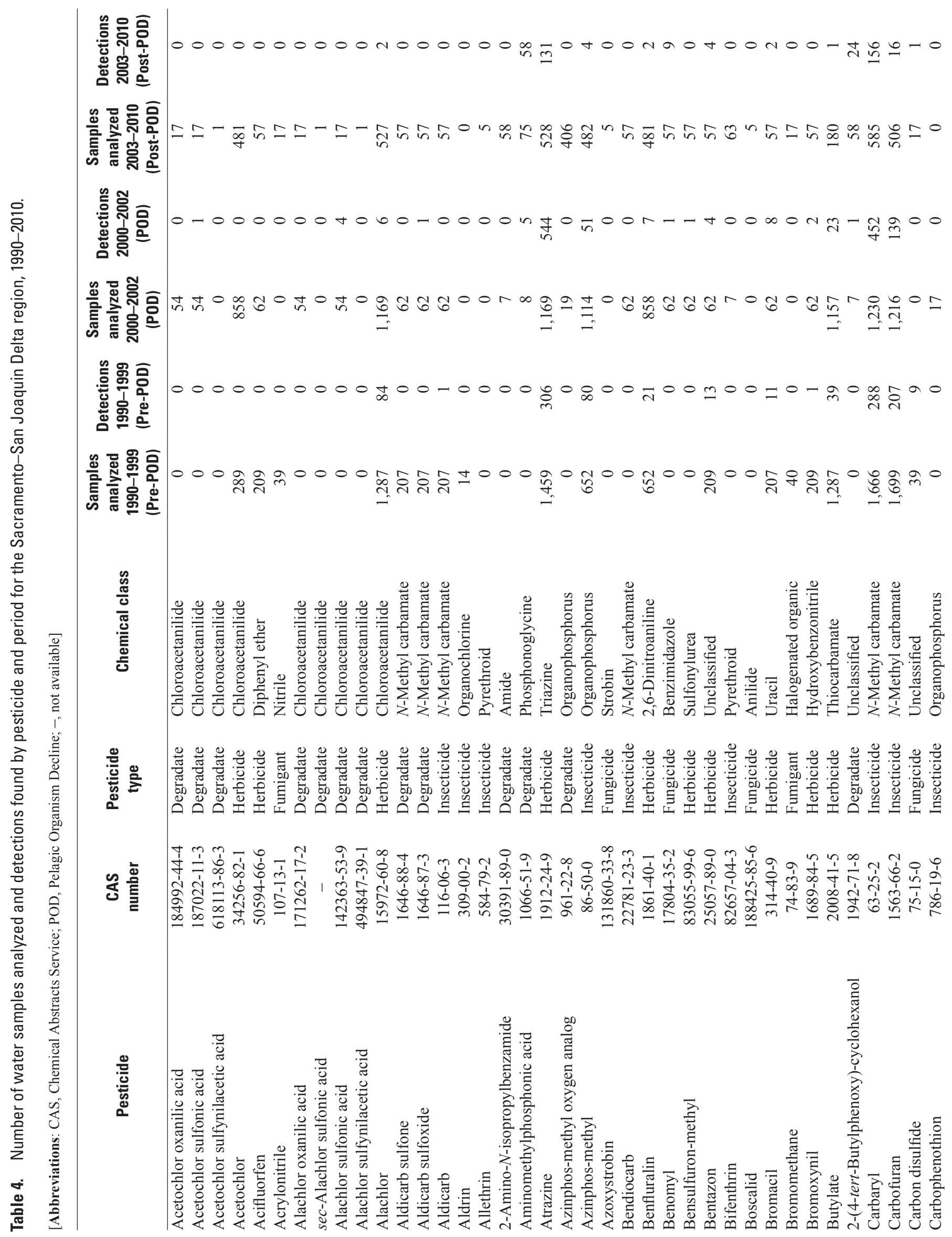




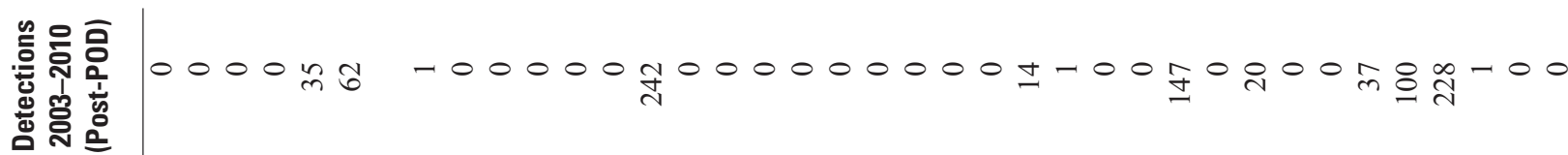

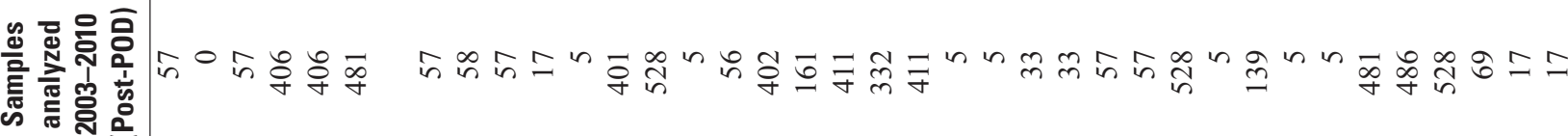

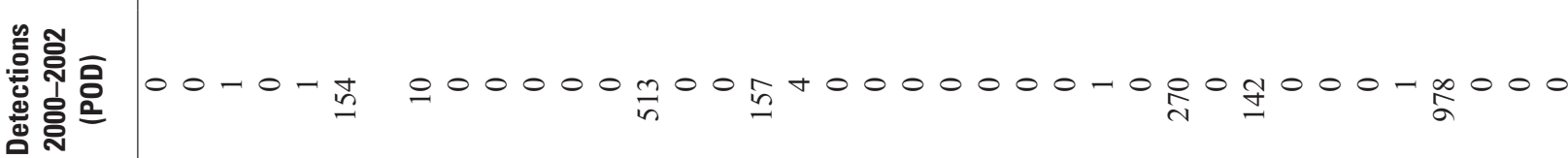

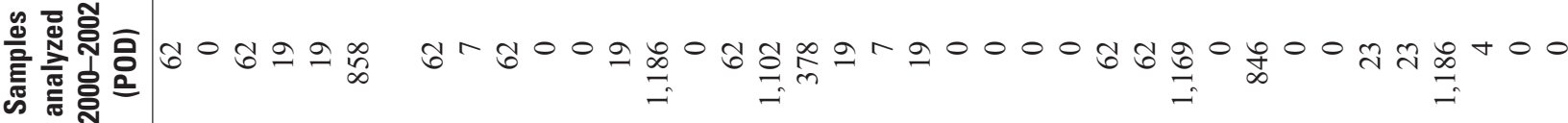

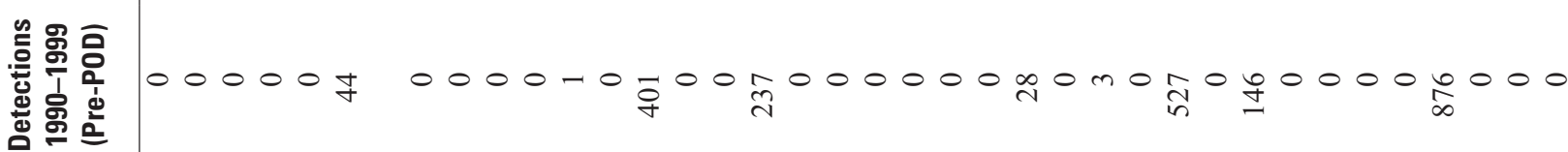

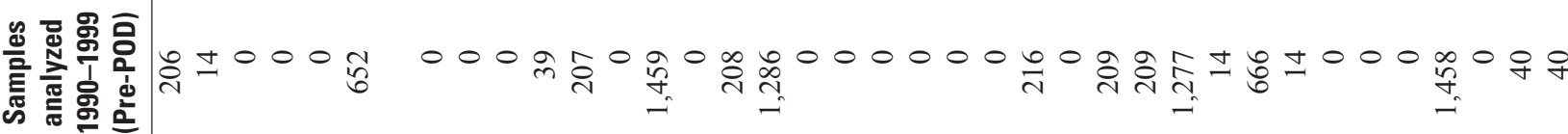

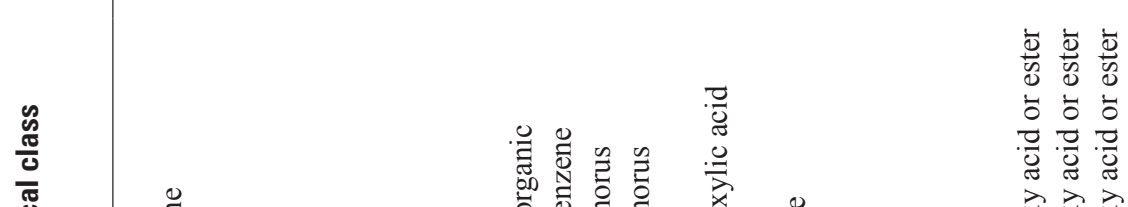




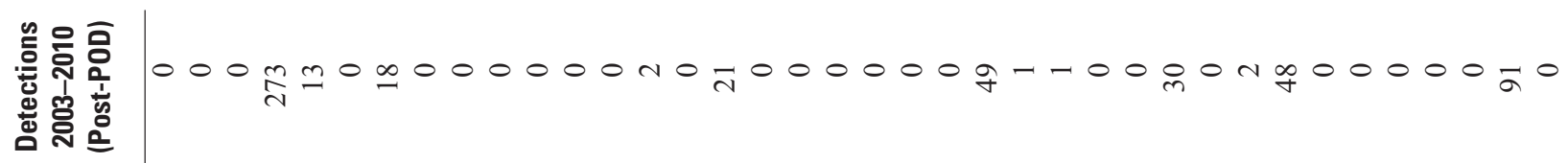

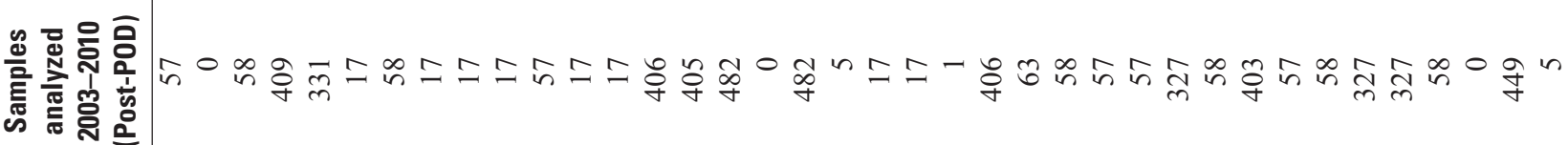

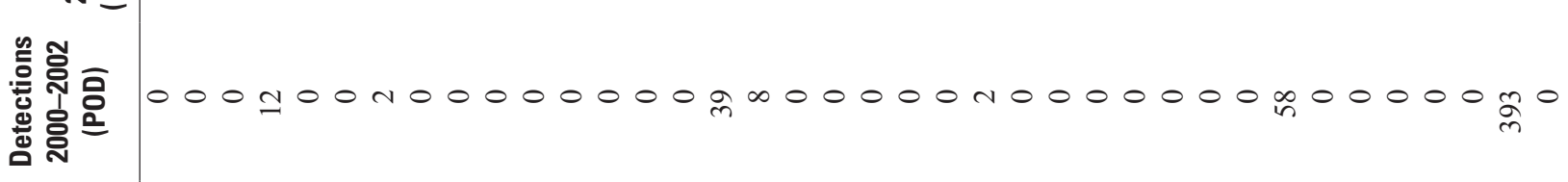

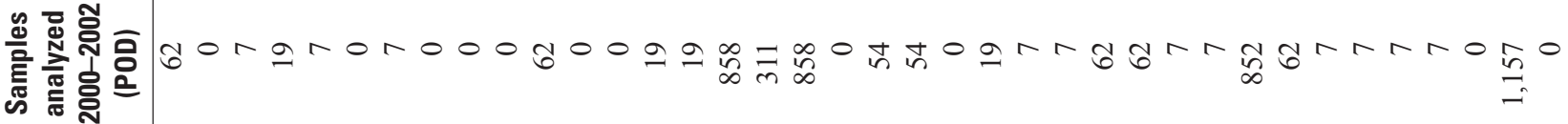

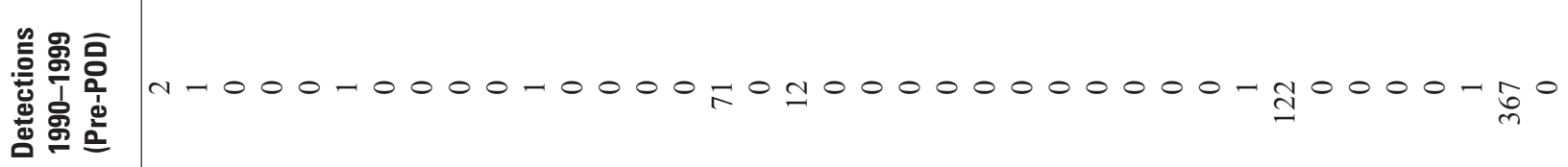

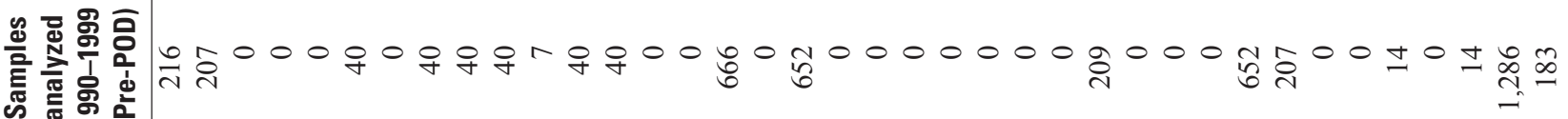

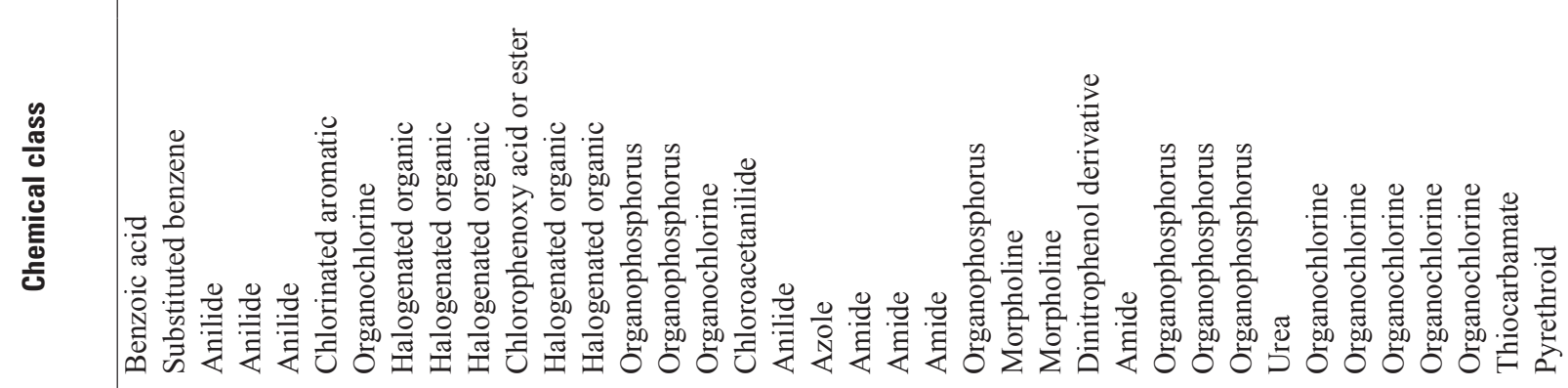

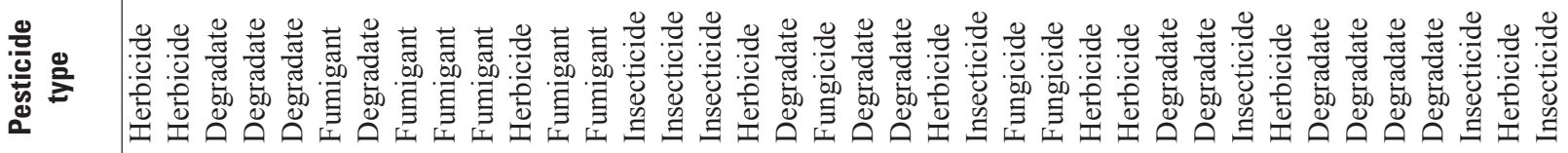
造

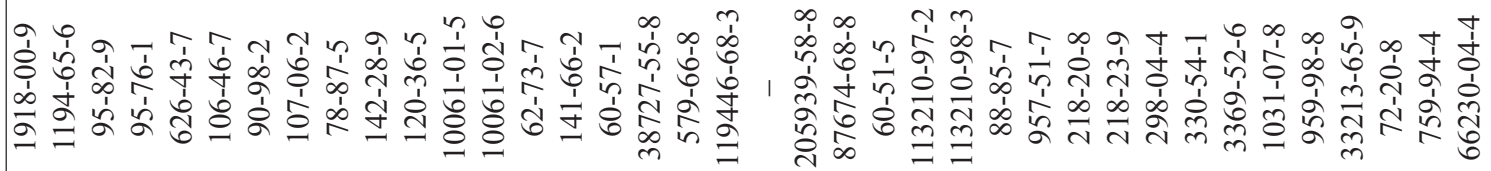

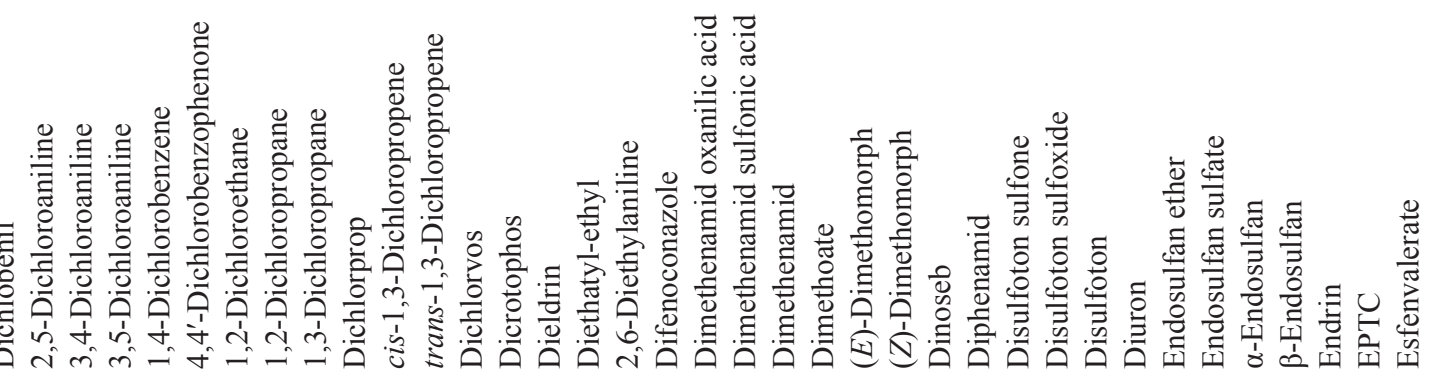




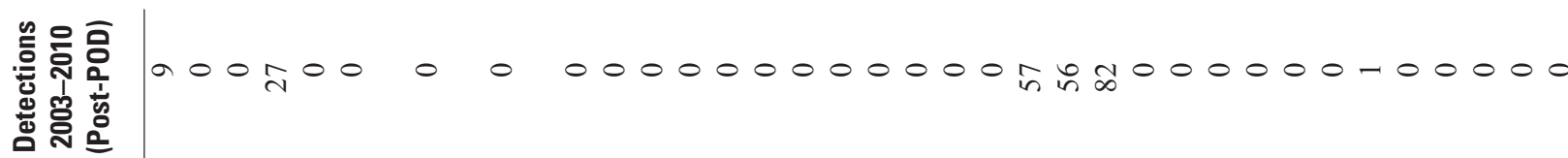




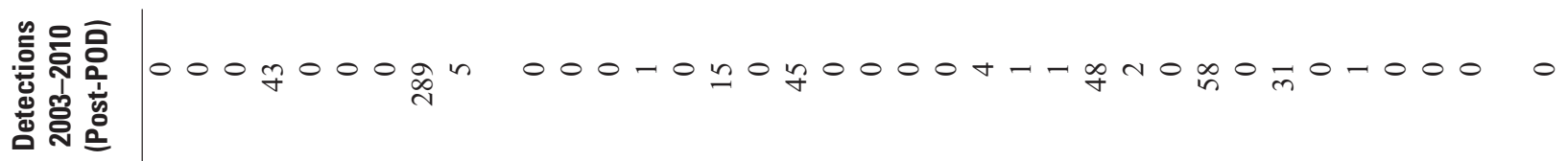

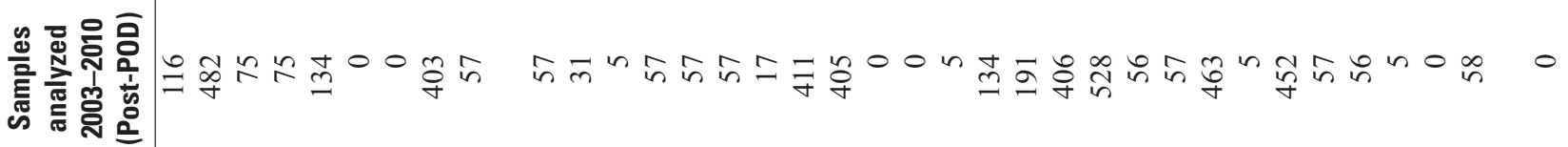

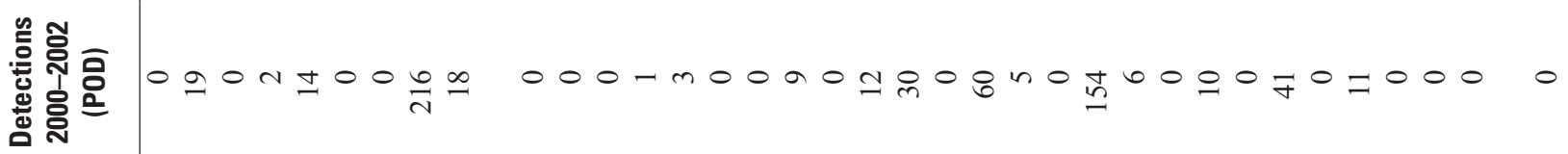

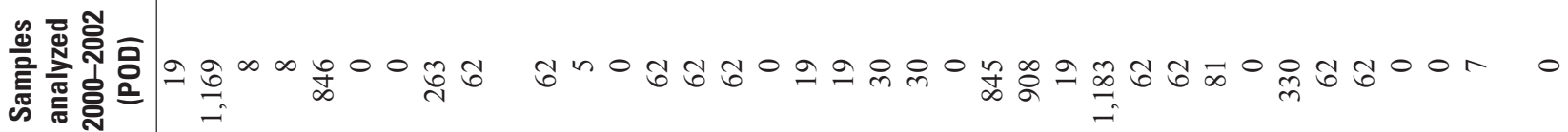
总亮旁

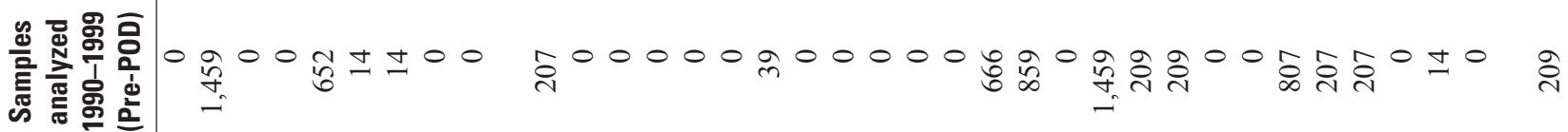

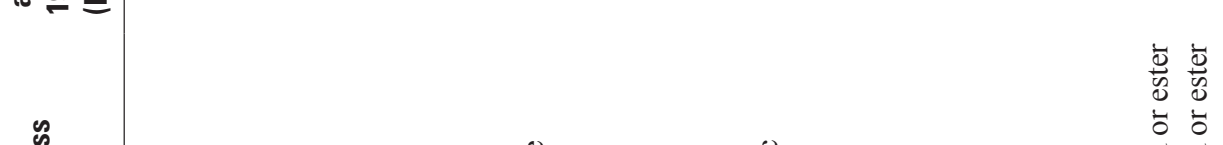
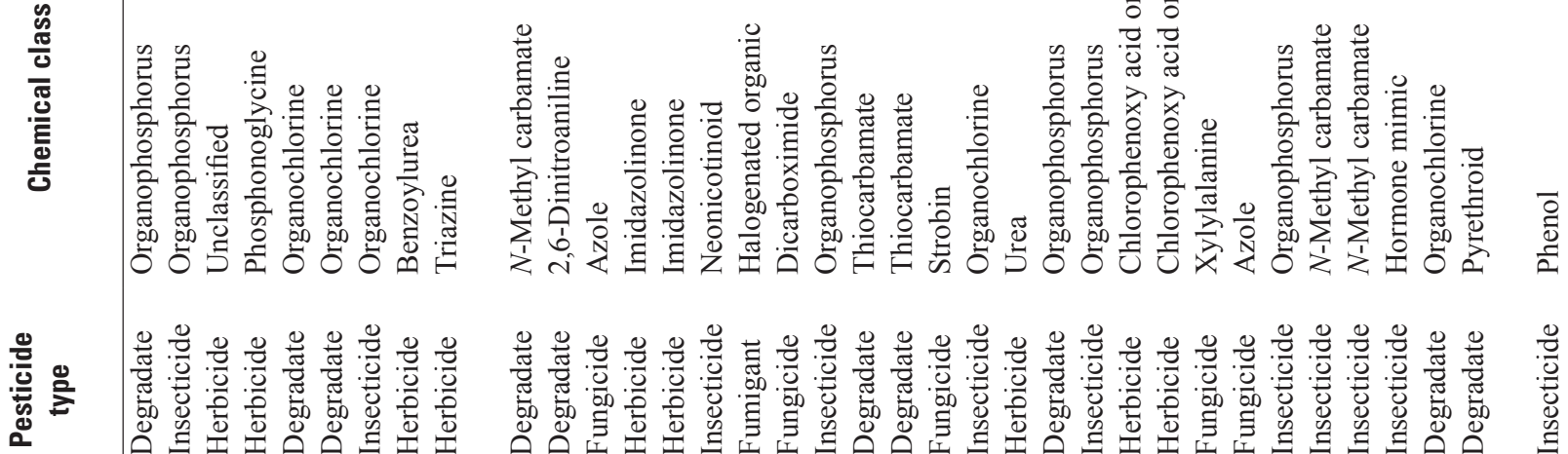

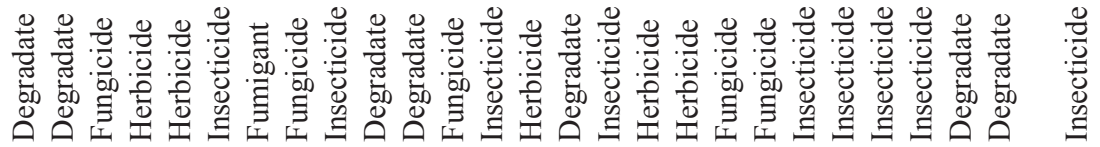

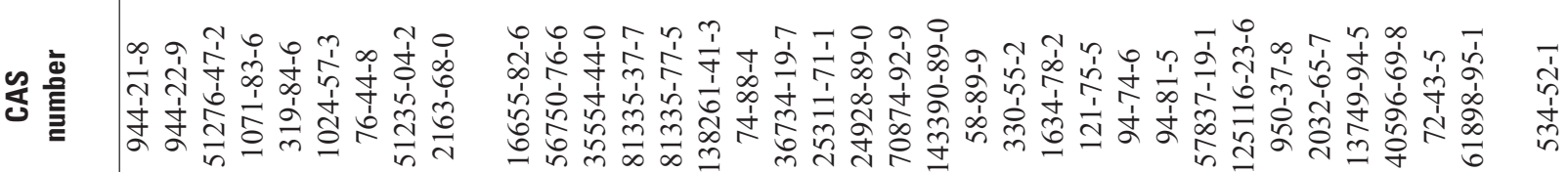

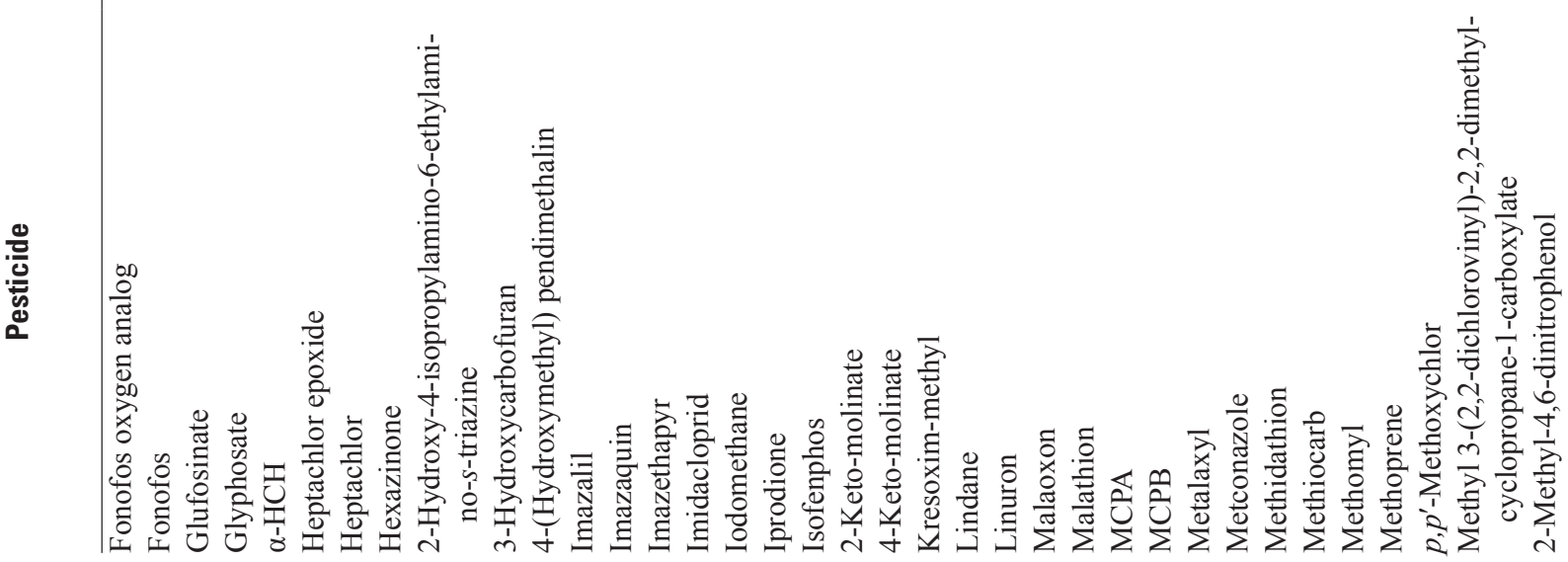




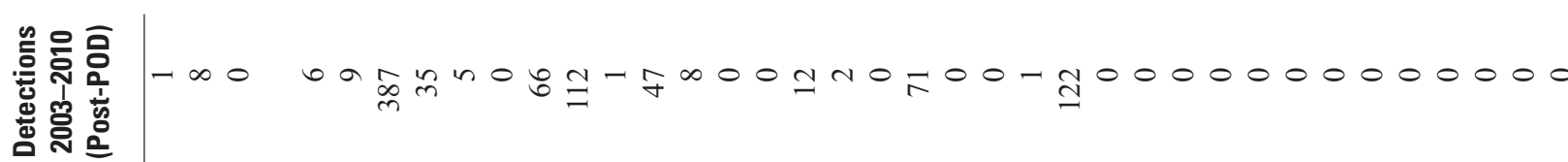

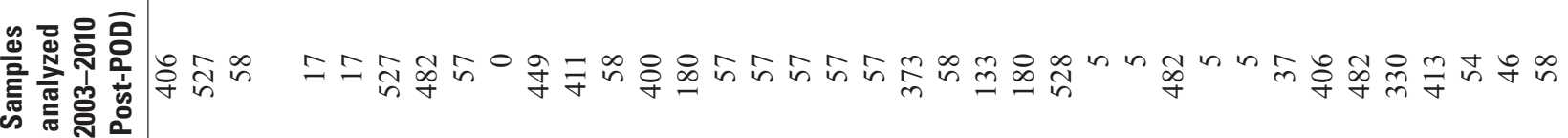

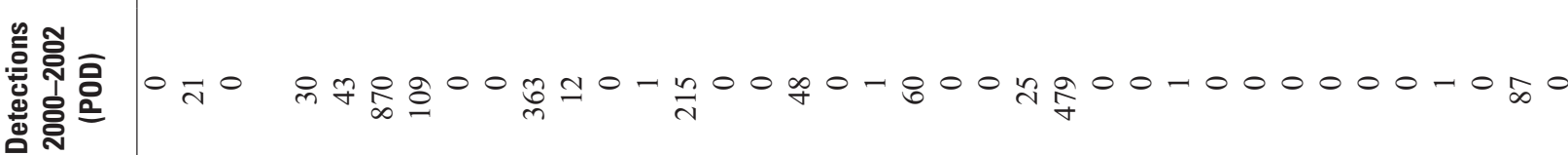

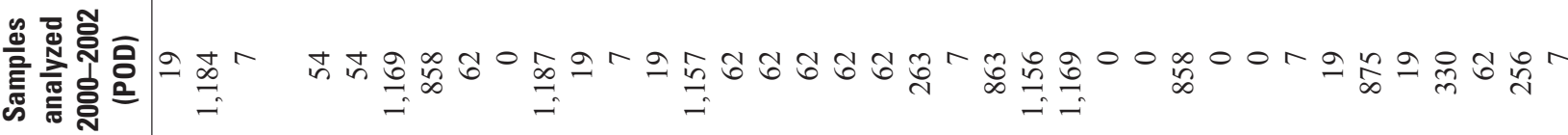

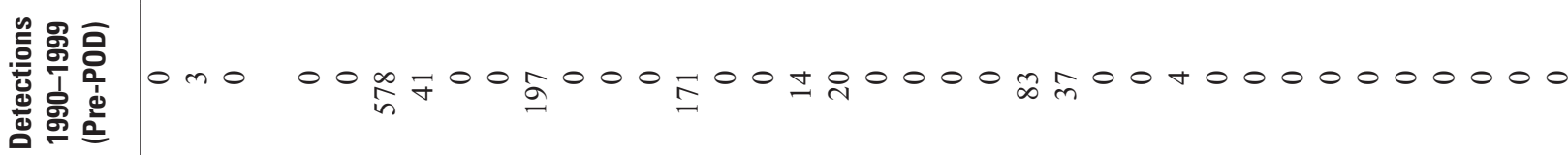

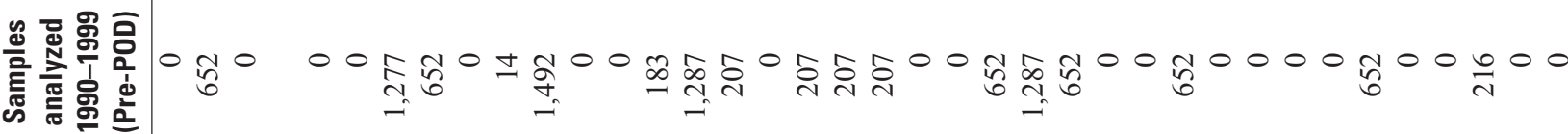
:

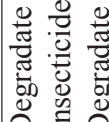

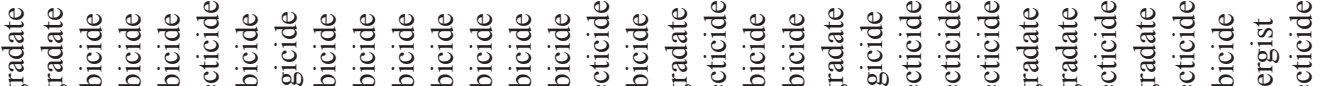

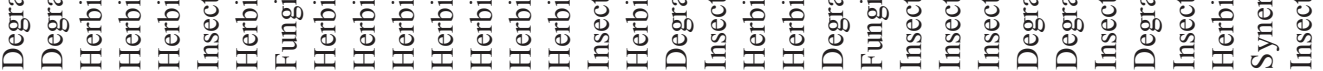

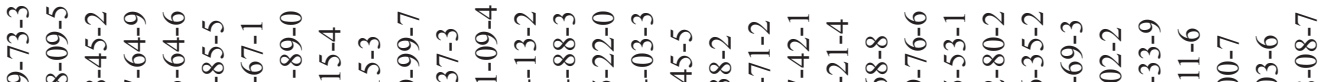

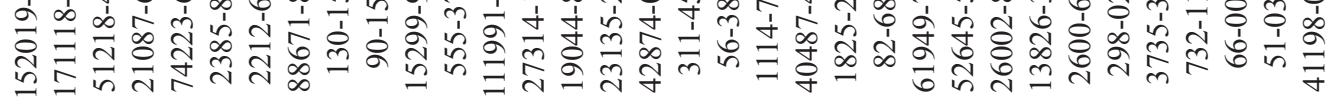

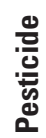

군

紊

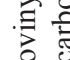

훈

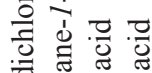

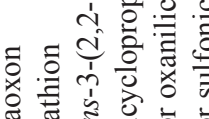

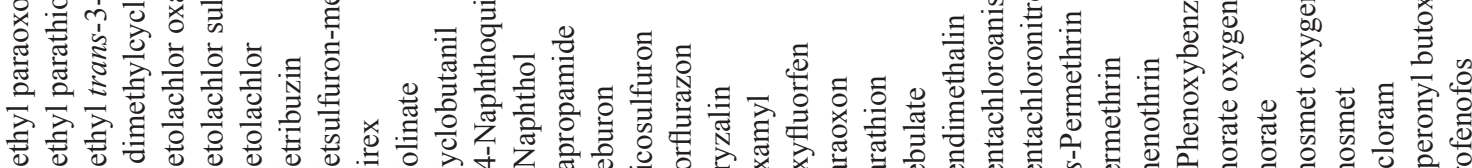

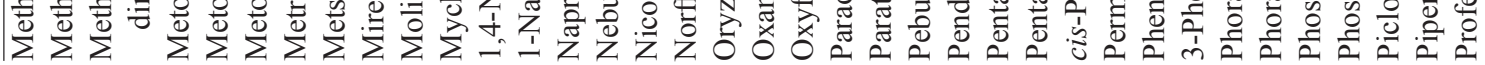




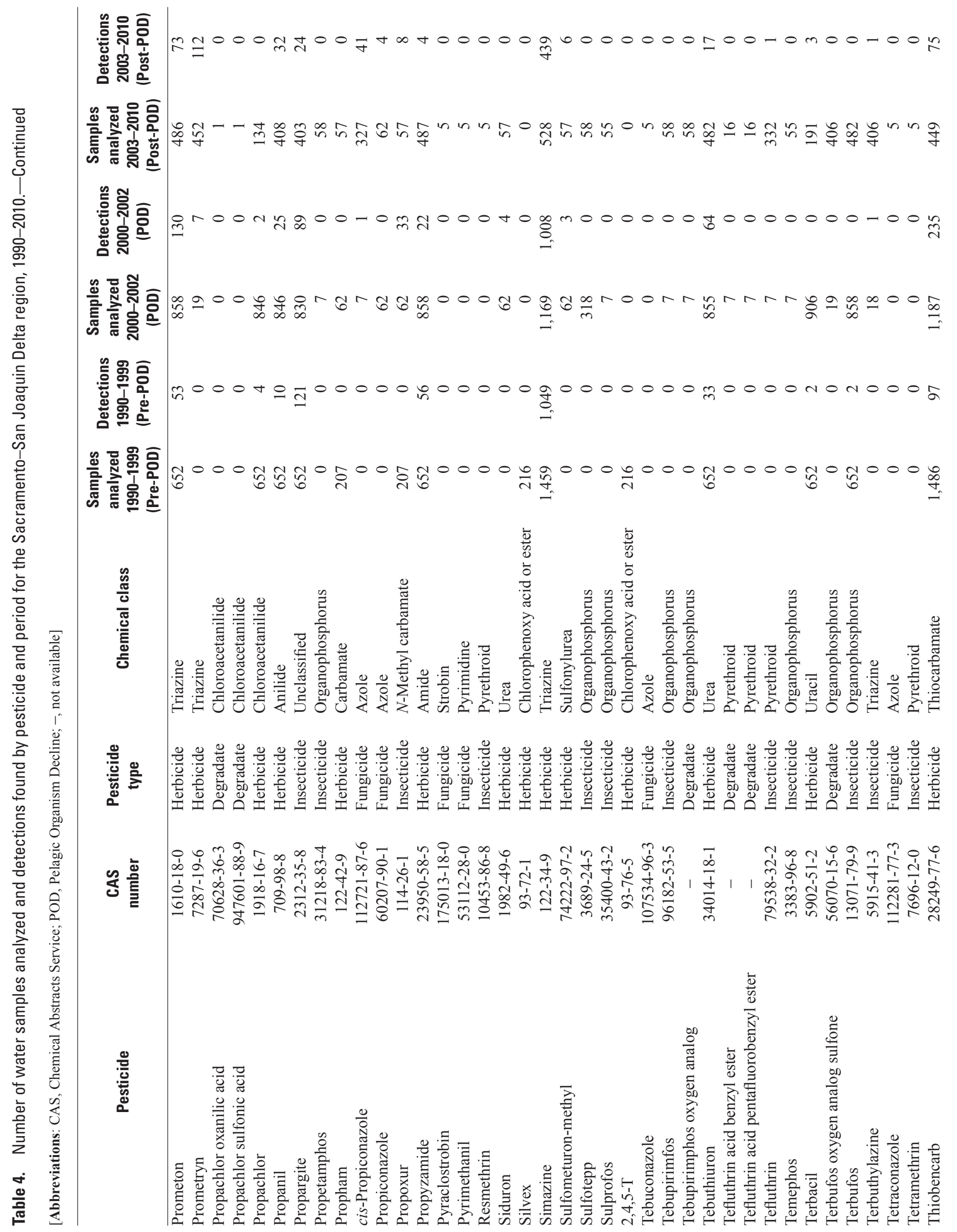




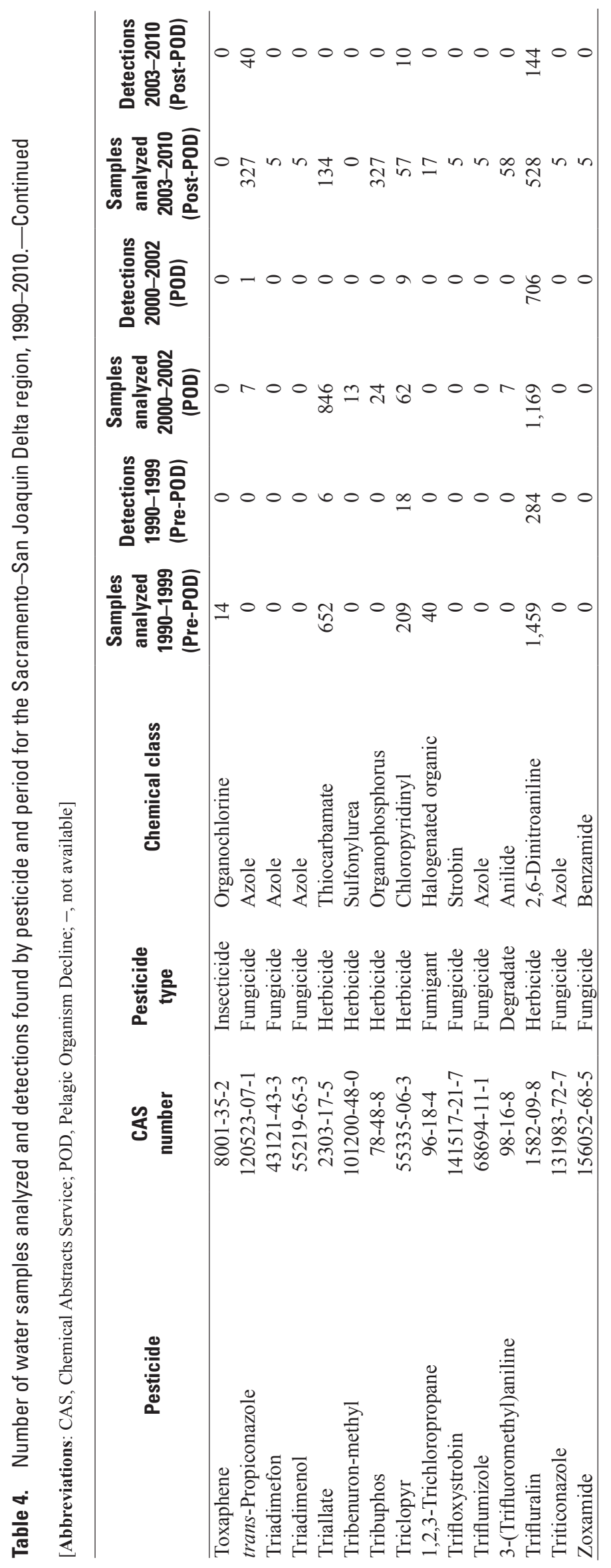


Table 5. Number of sediment samples analyzed and detections found by pesticide and period for the Sacramento-San Joaquin Delta region, 1990-2010.

[No sediment samples were analyzed during the 2000 to 2002 period. Abbreviations: CAS, Chemical Abstracts Service; POD, Pelagic Organism Decline; - , not available]

\begin{tabular}{|c|c|c|c|c|c|c|c|}
\hline Pesticide & $\begin{array}{c}\text { CAS } \\
\text { number }\end{array}$ & $\begin{array}{l}\text { Pesticide } \\
\text { type }\end{array}$ & $\begin{array}{c}\text { Chemical } \\
\text { class }\end{array}$ & $\begin{array}{c}\text { Samples } \\
\text { analyzed } \\
\text { 1990-1999 } \\
\text { (Pre-POD) }\end{array}$ & $\begin{array}{l}\text { Detections } \\
\text { 1990-1999 } \\
\text { (Pre-POD) }\end{array}$ & $\begin{array}{c}\text { Samples } \\
\text { analyzed } \\
\text { 2003-2010 } \\
\text { (Post-POD) }\end{array}$ & $\begin{array}{c}\text { Detections } \\
\text { 2003-2010 } \\
\text { (Post-P0D) }\end{array}$ \\
\hline Aldrin & 309-00-2 & Insecticide & Organochlorine & 46 & 1 & 1 & 0 \\
\hline Allethrin & $584-79-2$ & Insecticide & Pyrethroid & 0 & 0 & 74 & 0 \\
\hline Azoxystrobin & $131860-33-8$ & Fungicide & Strobin & 0 & 0 & 5 & 0 \\
\hline Bifenthrin & $82657-04-3$ & Insecticide & Pyrethroid & 0 & 0 & 74 & 59 \\
\hline Boscalid & $188425-85-6$ & Fungicide & Anilide & 0 & 0 & 5 & 0 \\
\hline Butylate & $2008-41-5$ & Herbicide & Thiocarbamate & 0 & 0 & 5 & 0 \\
\hline Carbaryl & $63-25-2$ & Insecticide & $N$-Methyl carbamate & 0 & 0 & 5 & 0 \\
\hline trans-Chlordane & $5103-74-2$ & Insecticide & Organochlorine & 20 & 2 & 1 & 1 \\
\hline Chlordane plus degradates & - & Degradate & Organochlorine & 67 & 21 & 0 & 0 \\
\hline Chloroneb & $2675-77-6$ & Fungicide & Substituted benzene & 20 & 0 & 0 & 0 \\
\hline Chlorothalonil & $1897-45-6$ & Fungicide & Substituted benzene & 0 & 0 & 5 & 0 \\
\hline Chlorpyrifos & $2921-88-2$ & Insecticide & Organophosphorus & 0 & 0 & 5 & 0 \\
\hline Clomazone & $81777-89-1$ & Herbicide & Unclassified & 0 & 0 & 5 & 0 \\
\hline$p$-Cresol & $106-44-5$ & Insecticide & Phenol & 21 & 10 & 0 & 0 \\
\hline Cycloate & $1134-23-2$ & Herbicide & Thiocarbamate & 0 & 0 & 5 & 0 \\
\hline Cyfluthrin & $68359-37-5$ & Insecticide & Pyrethroid & 0 & 0 & 74 & 4 \\
\hline$\lambda$-Cyhalothrin & $91465-08-6$ & Insecticide & Pyrethroid & 0 & 0 & 74 & 26 \\
\hline$o, p^{\prime}-\mathrm{DDE}$ & $3424-82-6$ & Degradate & Organochlorine & 21 & 4 & 0 & 0 \\
\hline$p, p^{\prime}-\mathrm{DDE}$ & $72-55-9$ & Degradate & Organochlorine & 21 & 18 & 6 & 0 \\
\hline DDT plus degradates & - & Degradate & Organochlorine & 37 & 21 & 0 & 0 \\
\hline$o, p^{\prime}-\mathrm{DDT}$ & $789-02-6$ & Insecticide & Organochlorine & 19 & 3 & 0 & 0 \\
\hline$p, p^{\prime}$-DDT & $50-29-3$ & Insecticide & Organochlorine & 45 & 31 & 6 & 0 \\
\hline Deltamethrin & $52918-63-5$ & Insecticide & Pyrethroid & 0 & 0 & 74 & 0 \\
\hline Desulfinylfipronil & - & Degradate & Pyrazole & 0 & 0 & 5 & 0 \\
\hline Diazinon & $333-41-5$ & Insecticide & Organophosphorus & 0 & 0 & 5 & 0 \\
\hline 3,4-Dichloroaniline & $95-76-1$ & Degradate & Anilide & 0 & 0 & 5 & 0 \\
\hline 3,5-Dichloroaniline & $626-43-7$ & Degradate & Anilide & 0 & 0 & 5 & 0 \\
\hline 1,4-Dichlorobenzene & $106-46-7$ & Fumigant & Chlorinated aromatic & 21 & 0 & 0 & 0 \\
\hline Dieldrin & $60-57-1$ & Insecticide & Organochlorine & 46 & 24 & 1 & 0 \\
\hline Difenoconazole & $119446-68-3$ & Fungicide & Azole & 0 & 0 & 5 & 0 \\
\hline (E)-Dimethomorph & $113210-97-2$ & Fungicide & Phenol & 0 & 0 & 5 & 0 \\
\hline 2-Methyl-4,6-dinitrophenol & $534-52-1$ & Insecticide & Phenol & 2 & 2 & 0 & 0 \\
\hline Disulfoton & $298-04-4$ & Insecticide & Organophosphorus & 0 & 0 & 5 & 0 \\
\hline
\end{tabular}


Table 5. Number of sediment samples analyzed and detections found by pesticide and period for the Sacramento-San Joaquin Delta region, 1990-2010.-Continued

[No sediment samples were analyzed during the 2000 to 2002 period. Abbreviations: CAS, Chemical Abstracts Service; POD, Pelagic Organism Decline; - , not available]

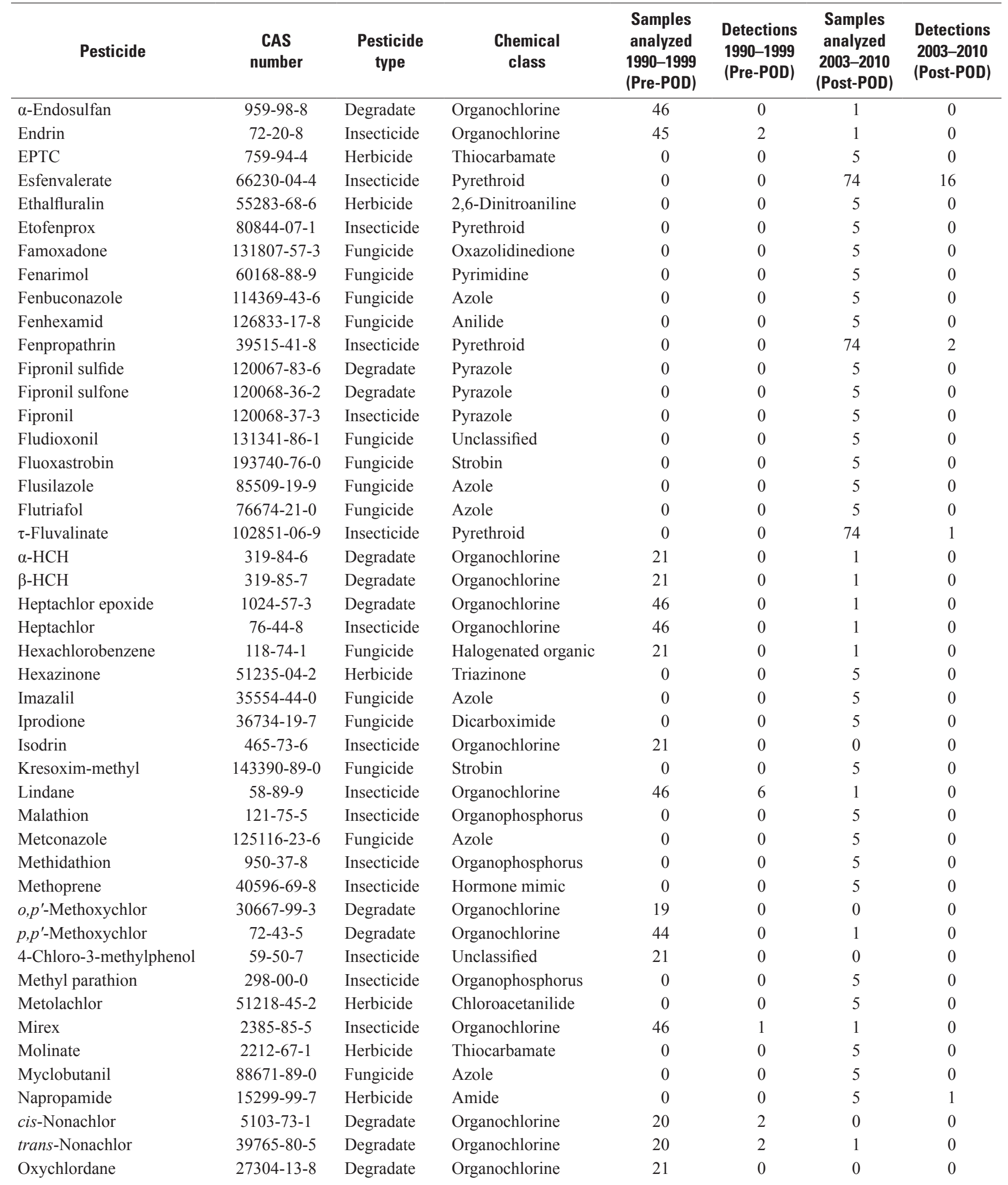


Table 5. Number of sediment samples analyzed and detections found by pesticide and period for the Sacramento-San Joaquin Delta region, 1990-2010.-Continued

[No sediment samples were analyzed during the 2000 to 2002 period. Abbreviations: CAS, Chemical Abstracts Service; POD, Pelagic Organism Decline; - , not available]

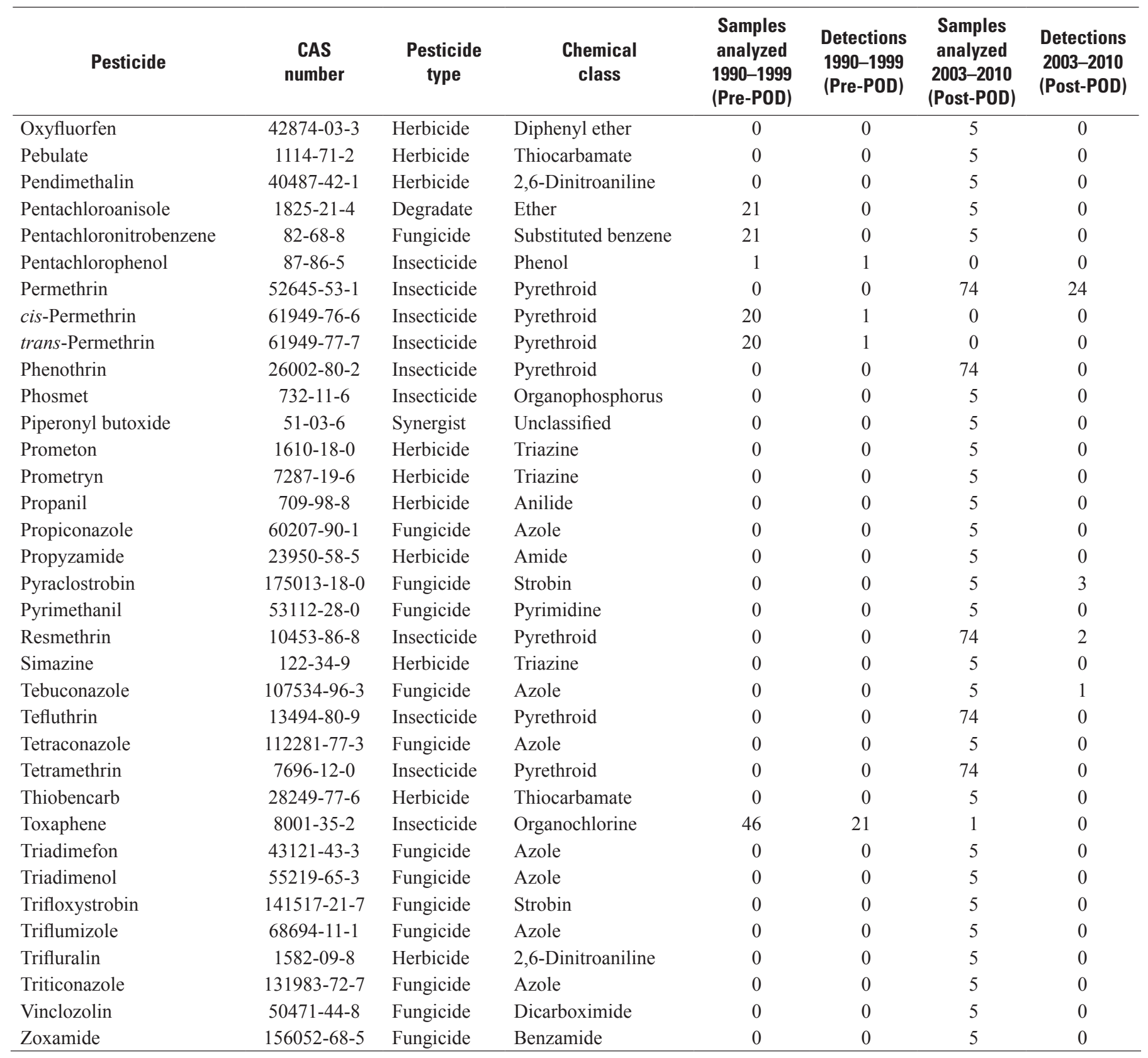




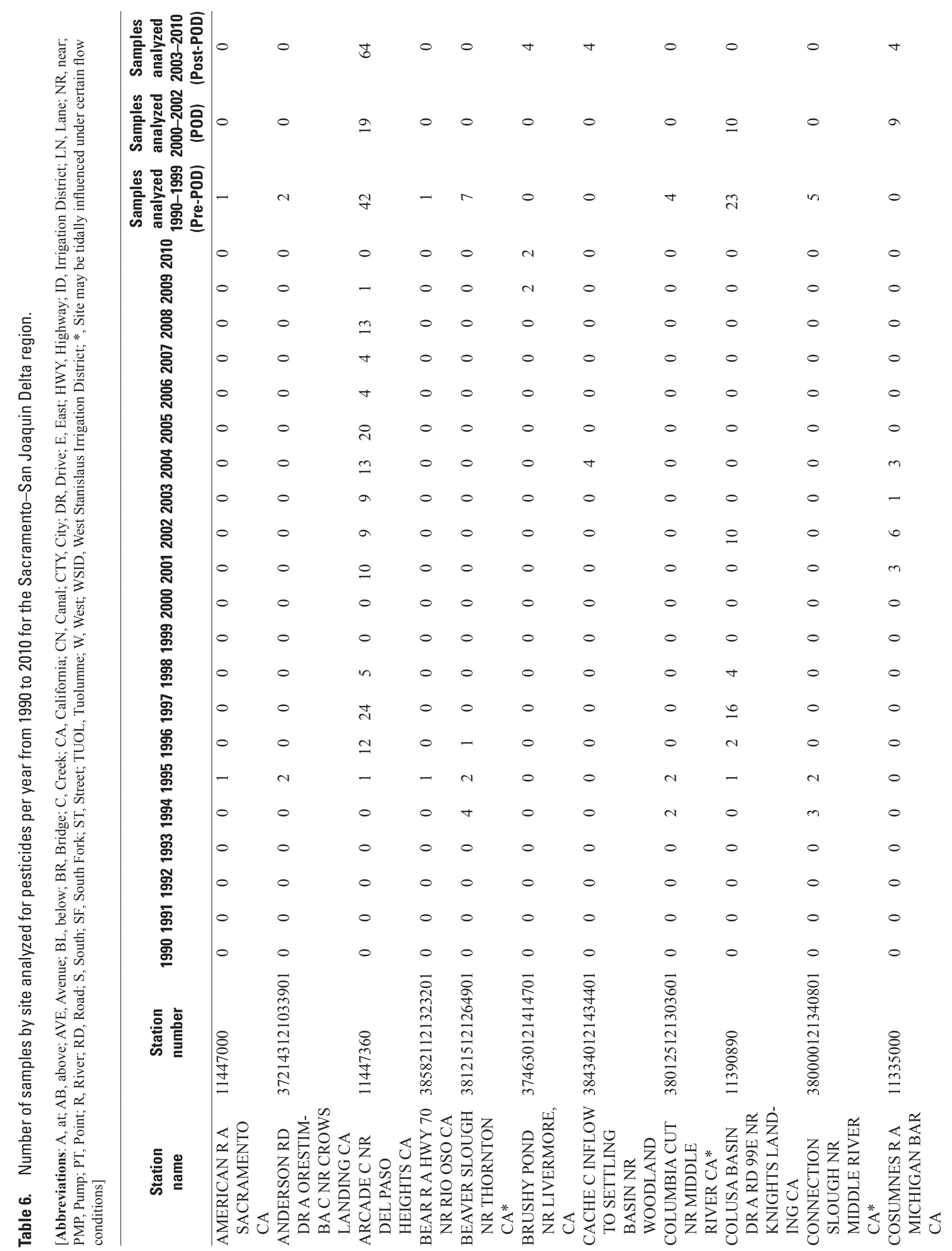




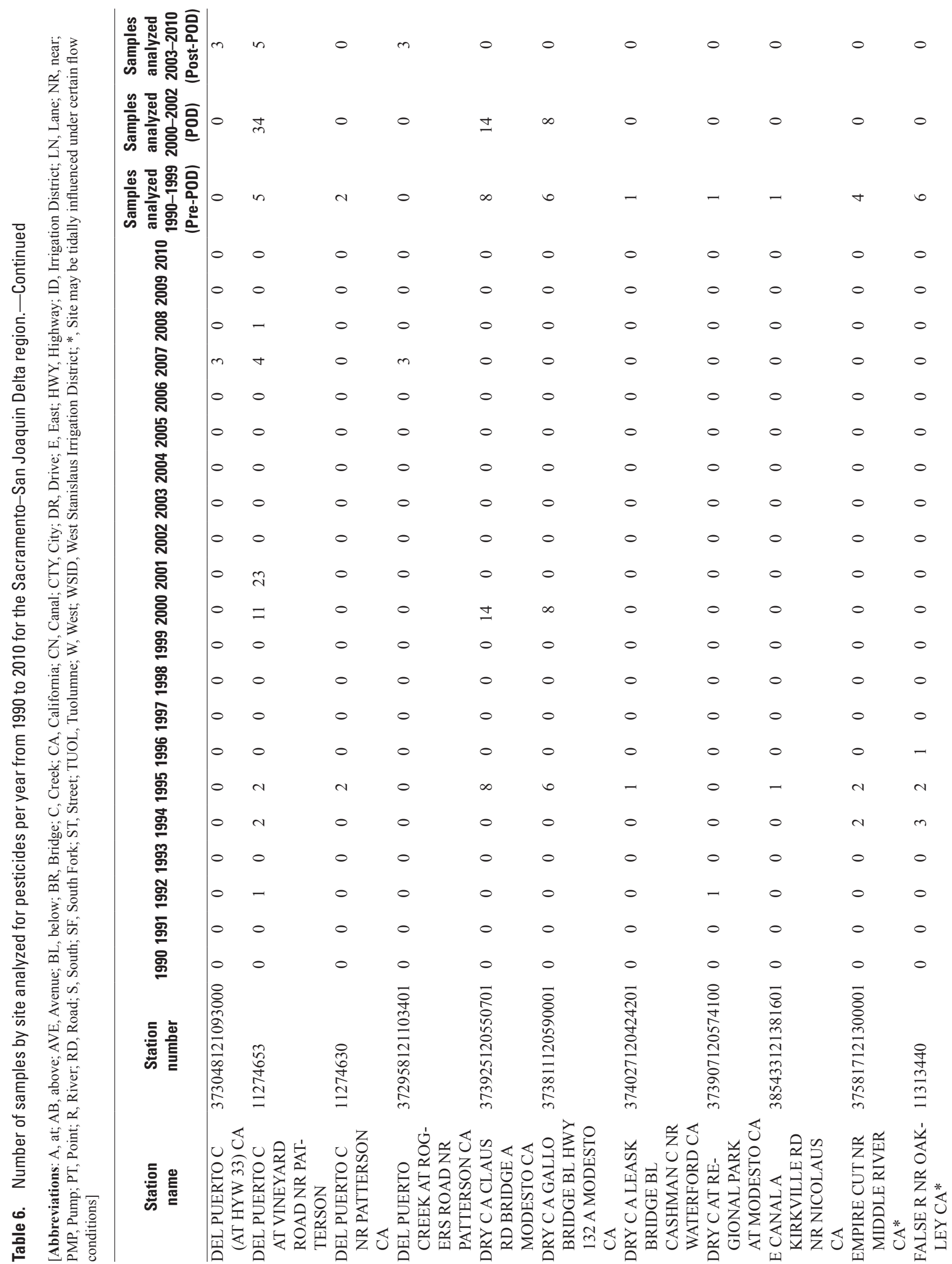




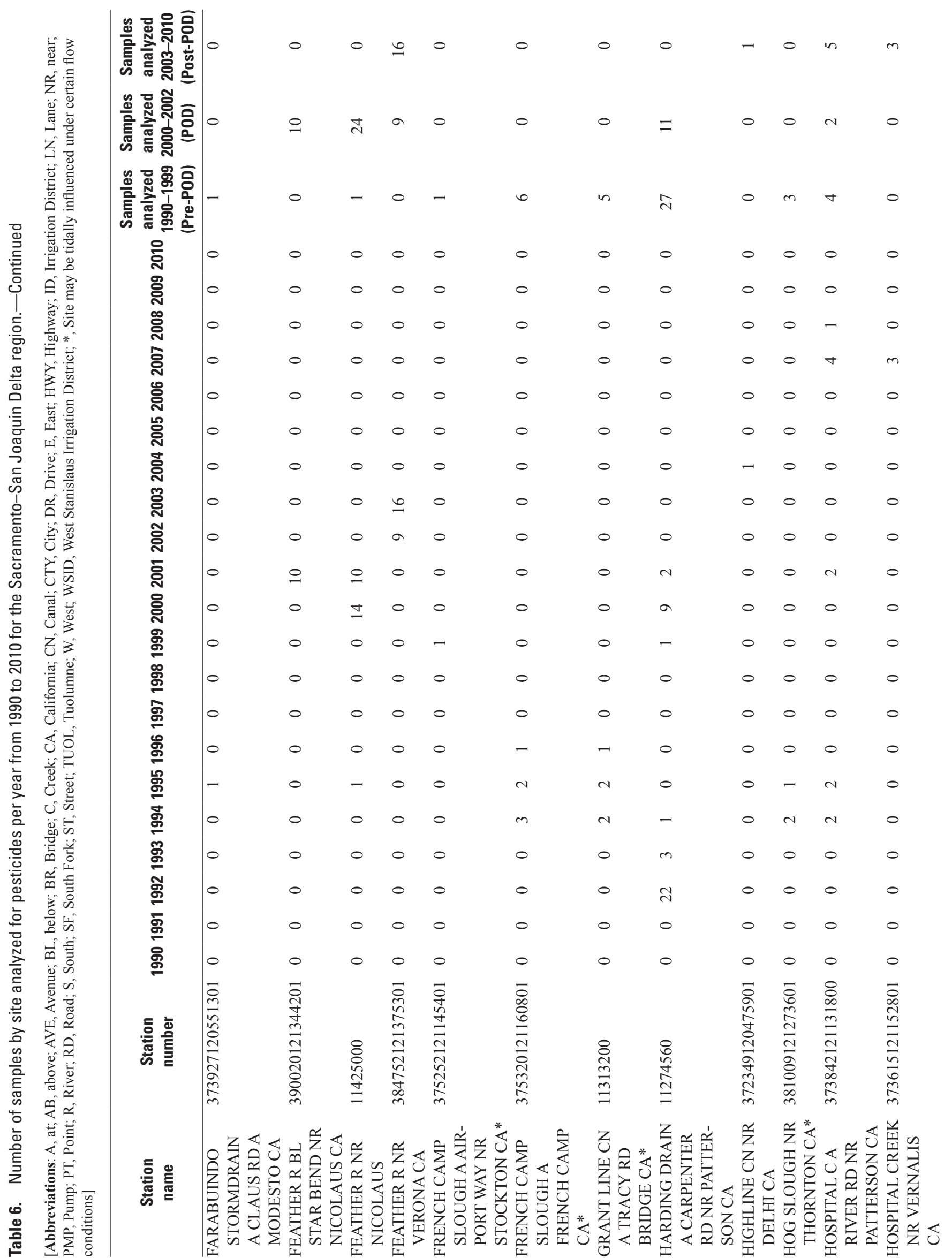




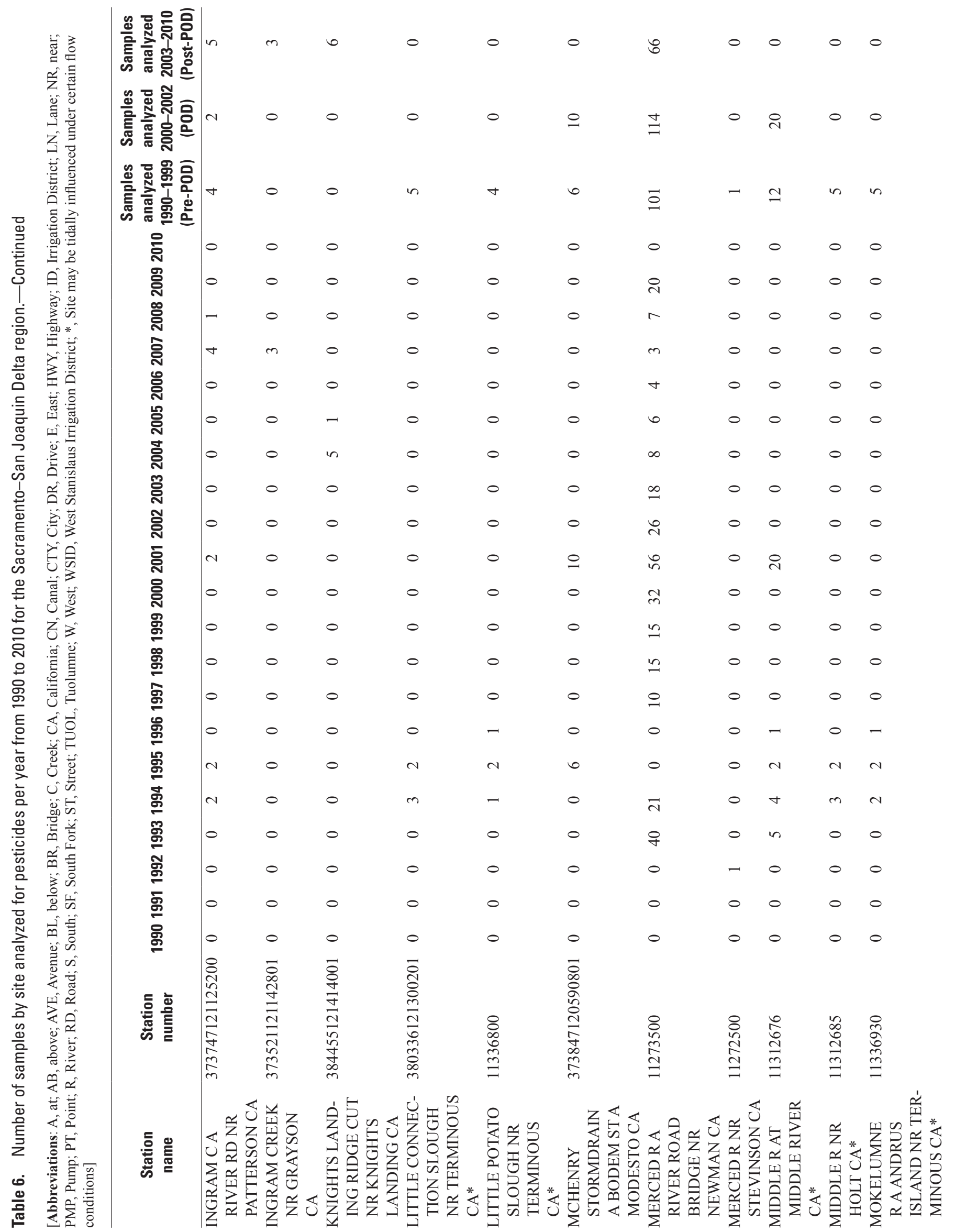




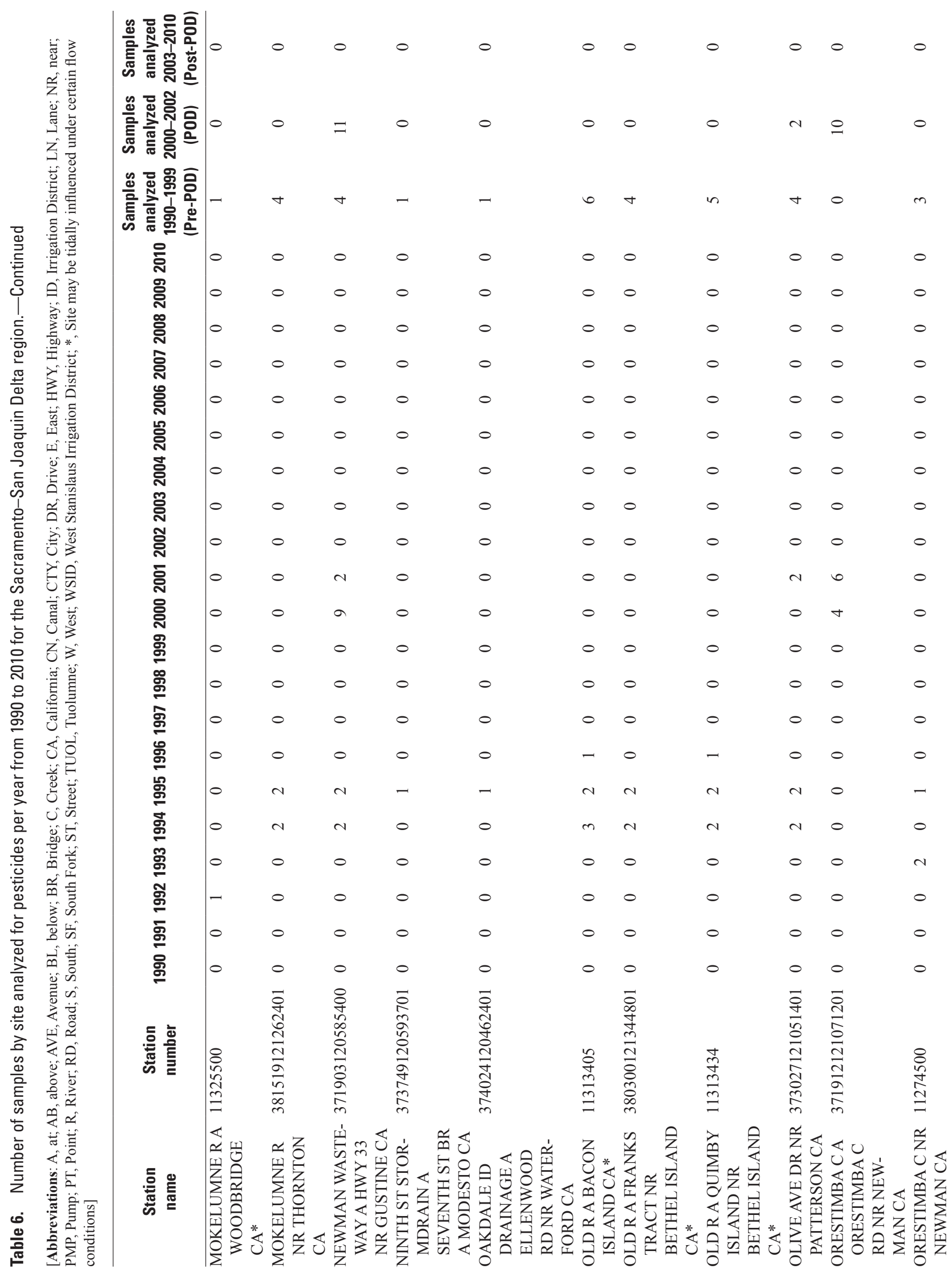




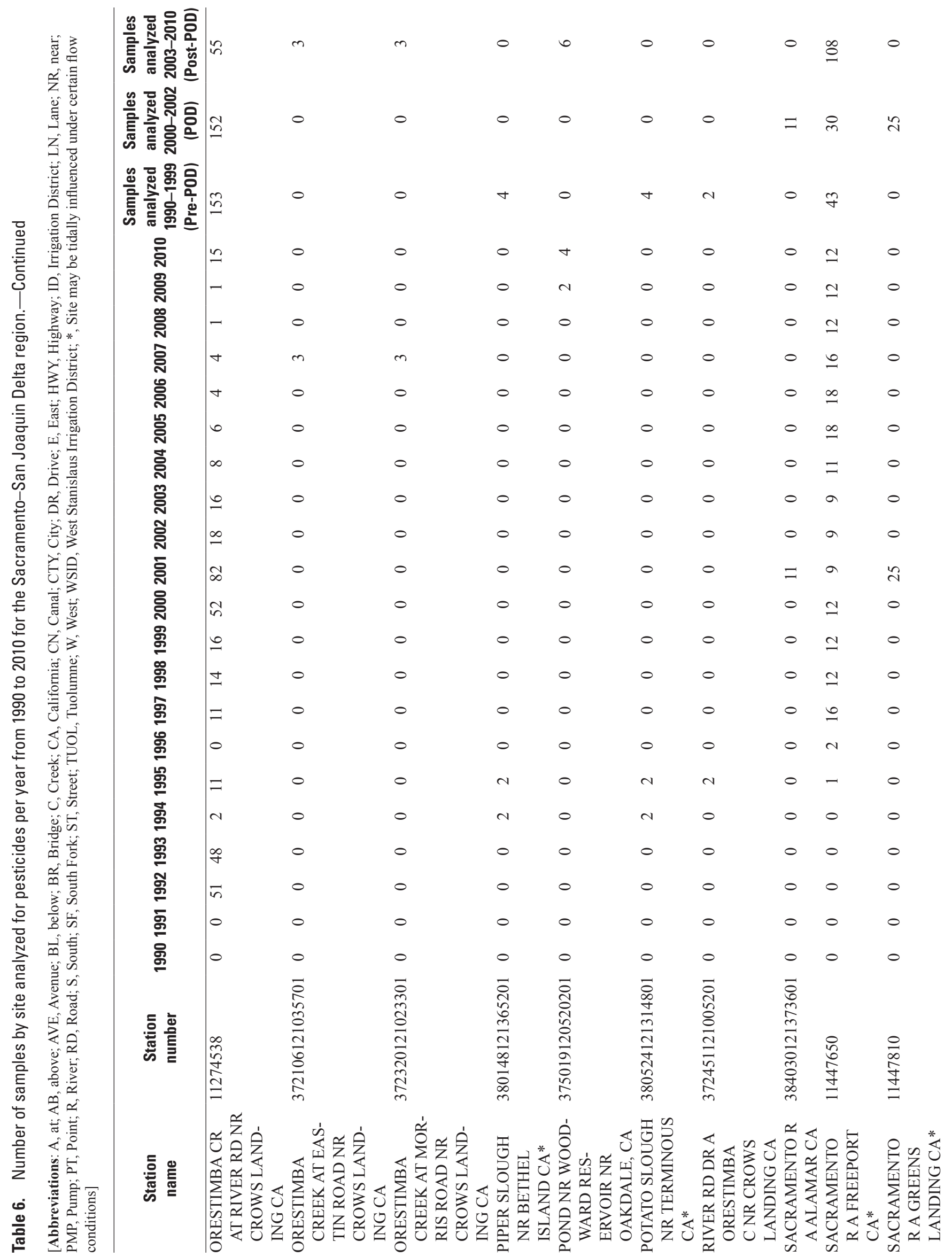




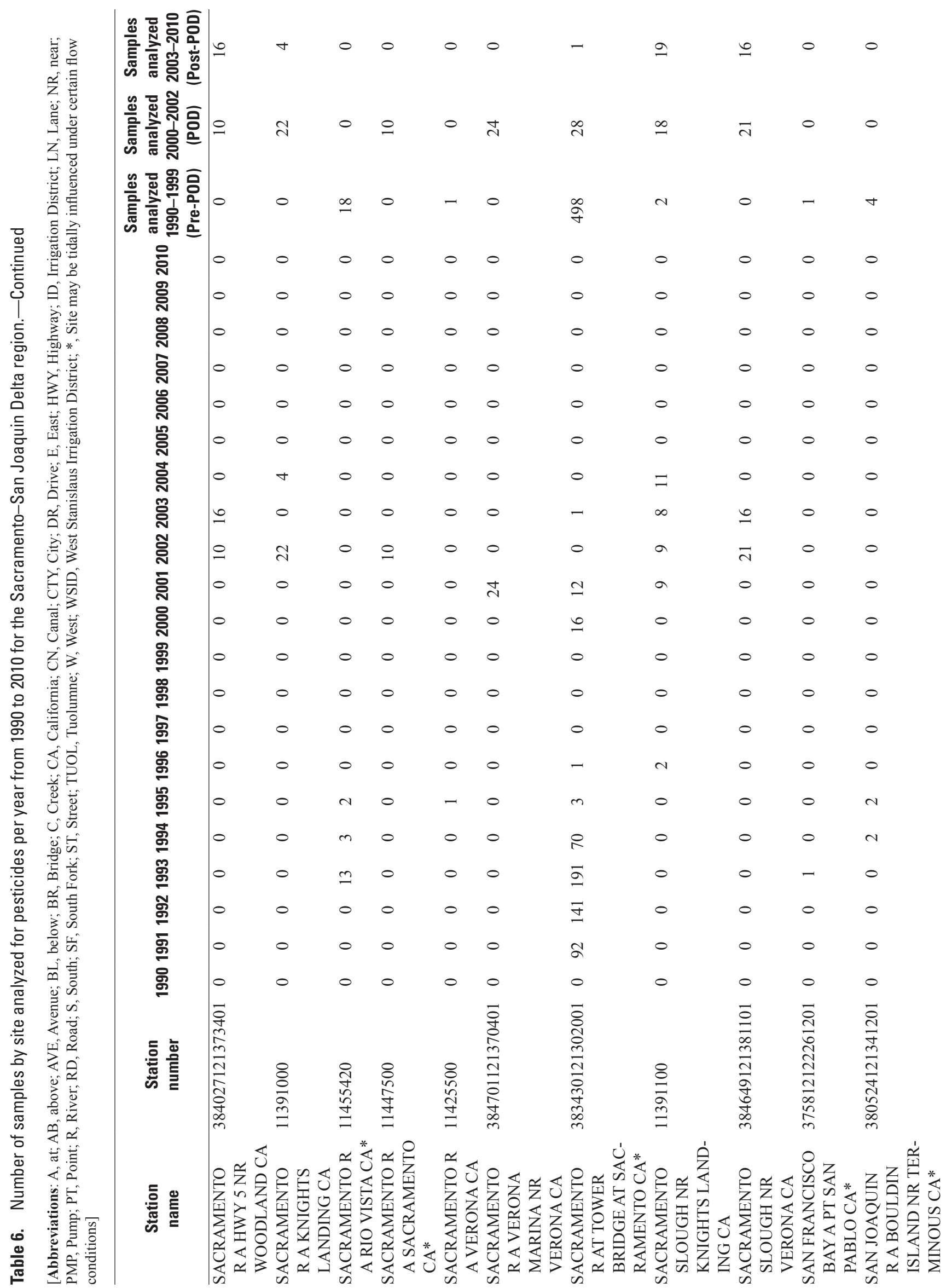




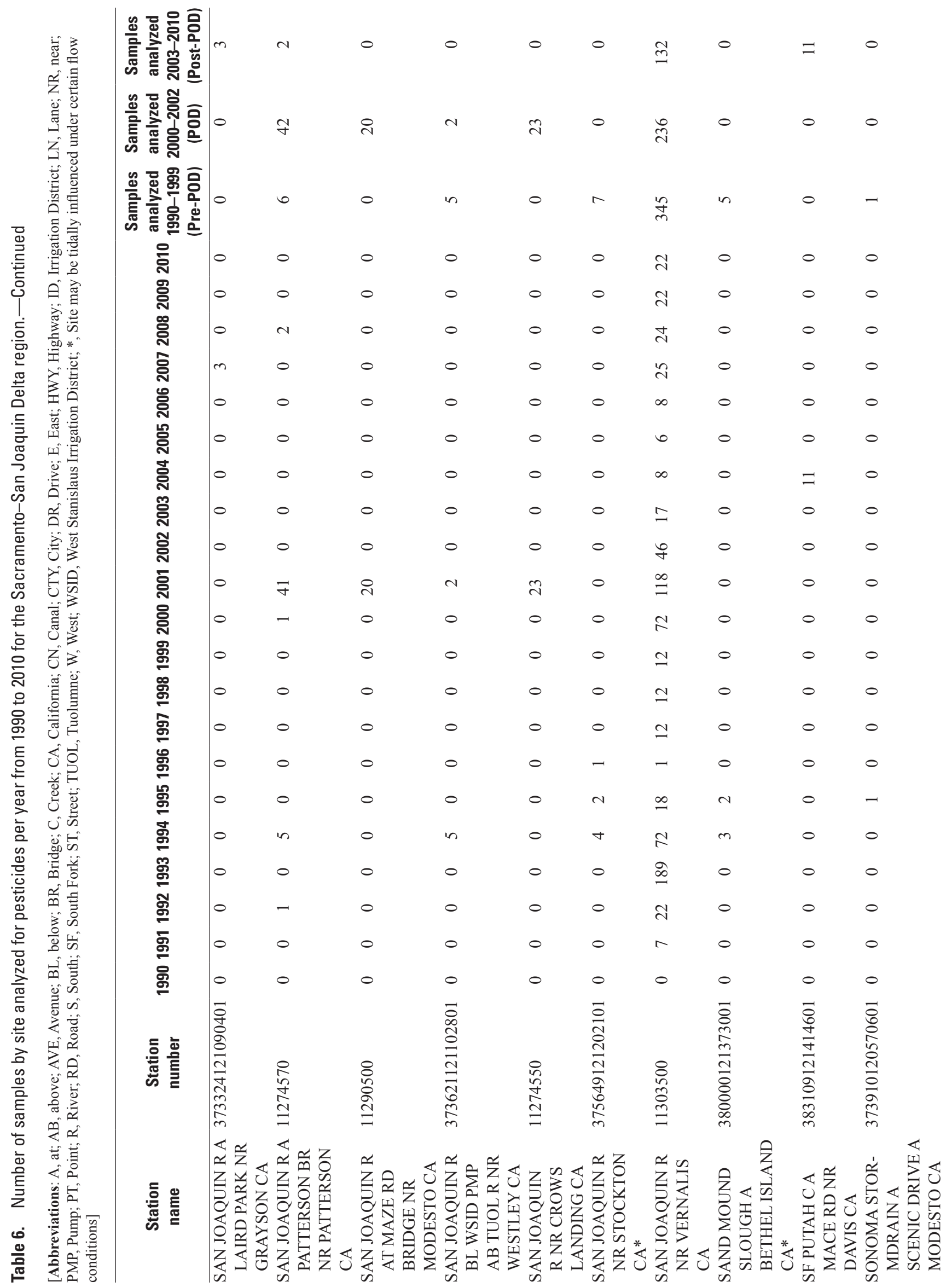




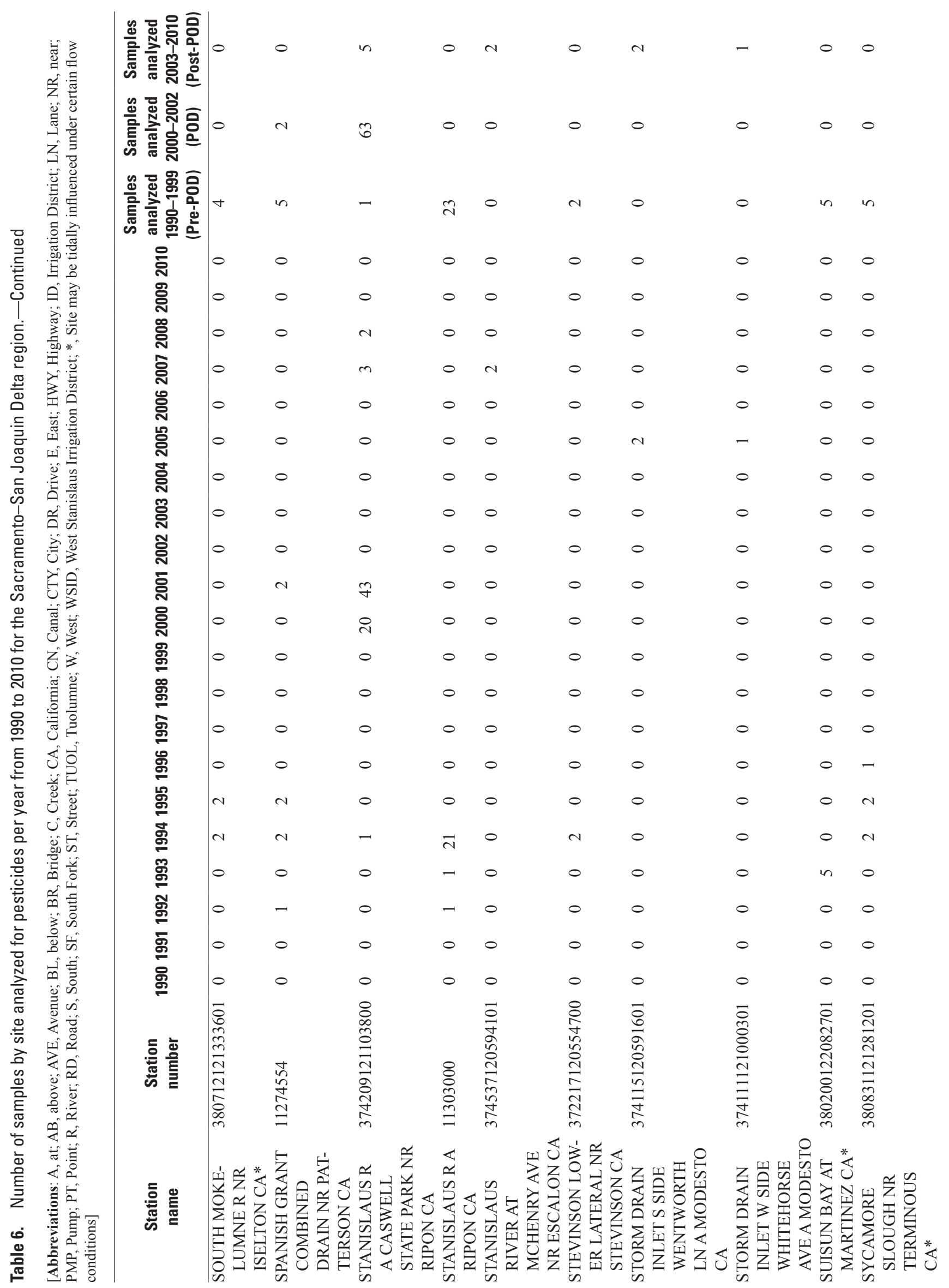




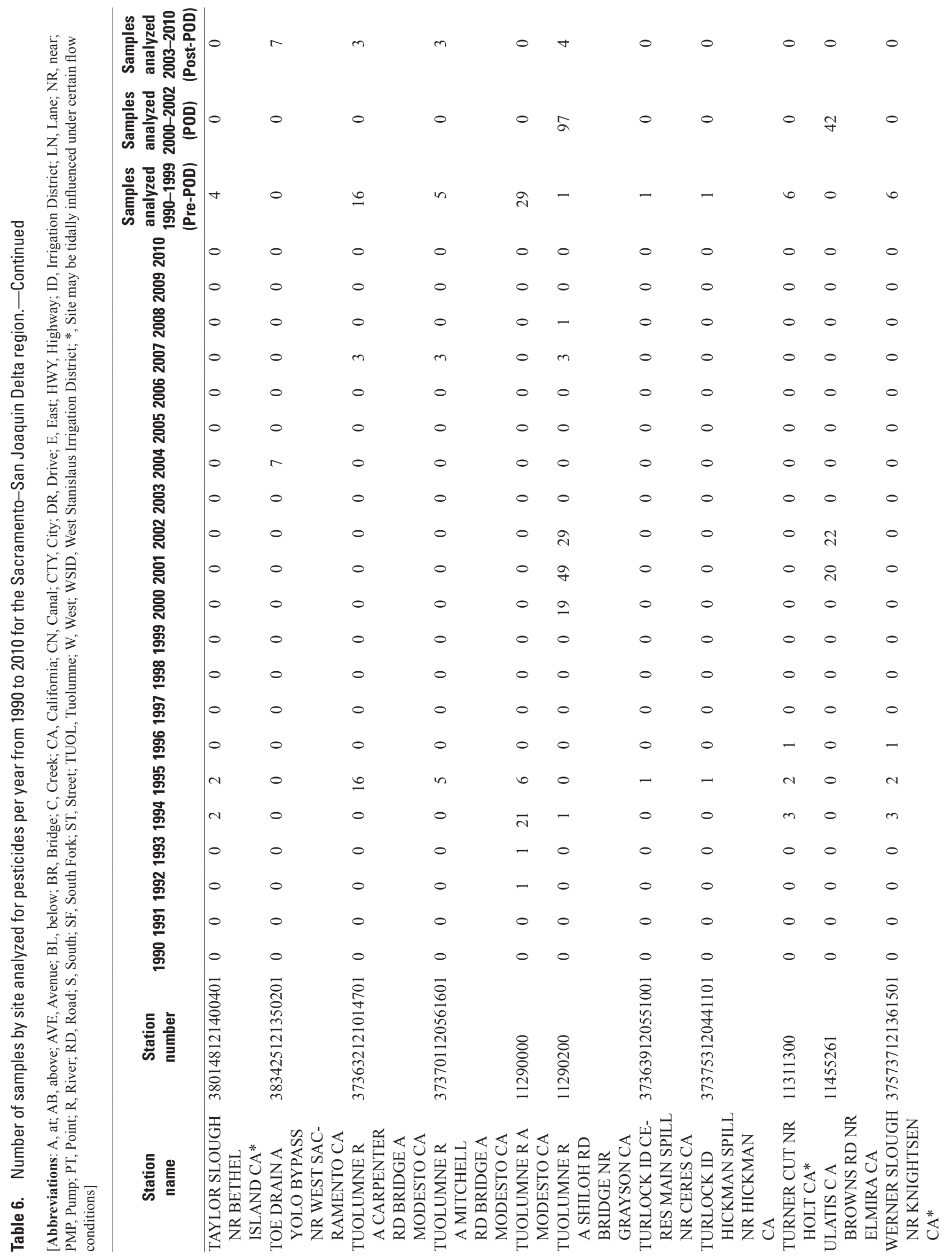




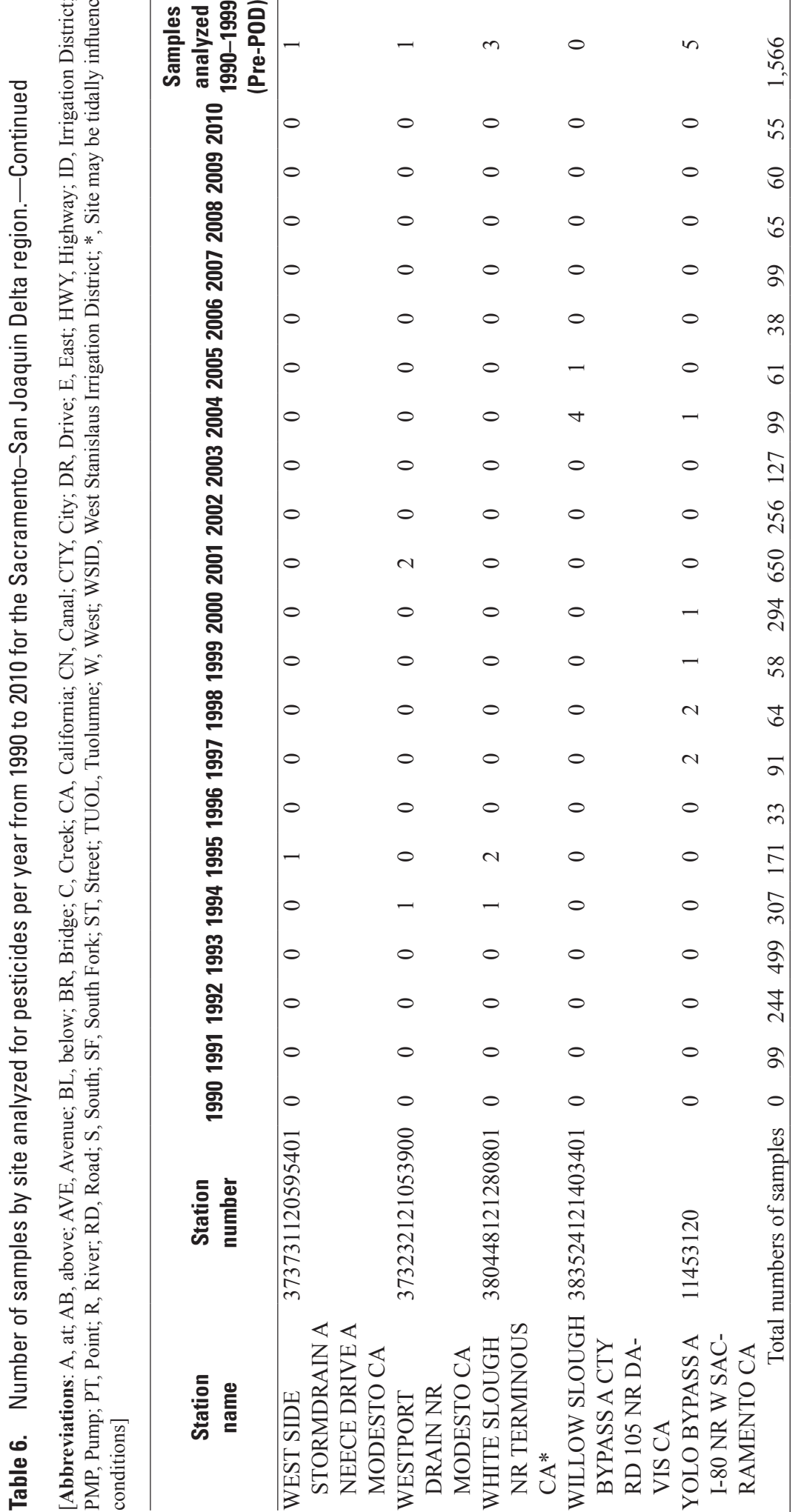




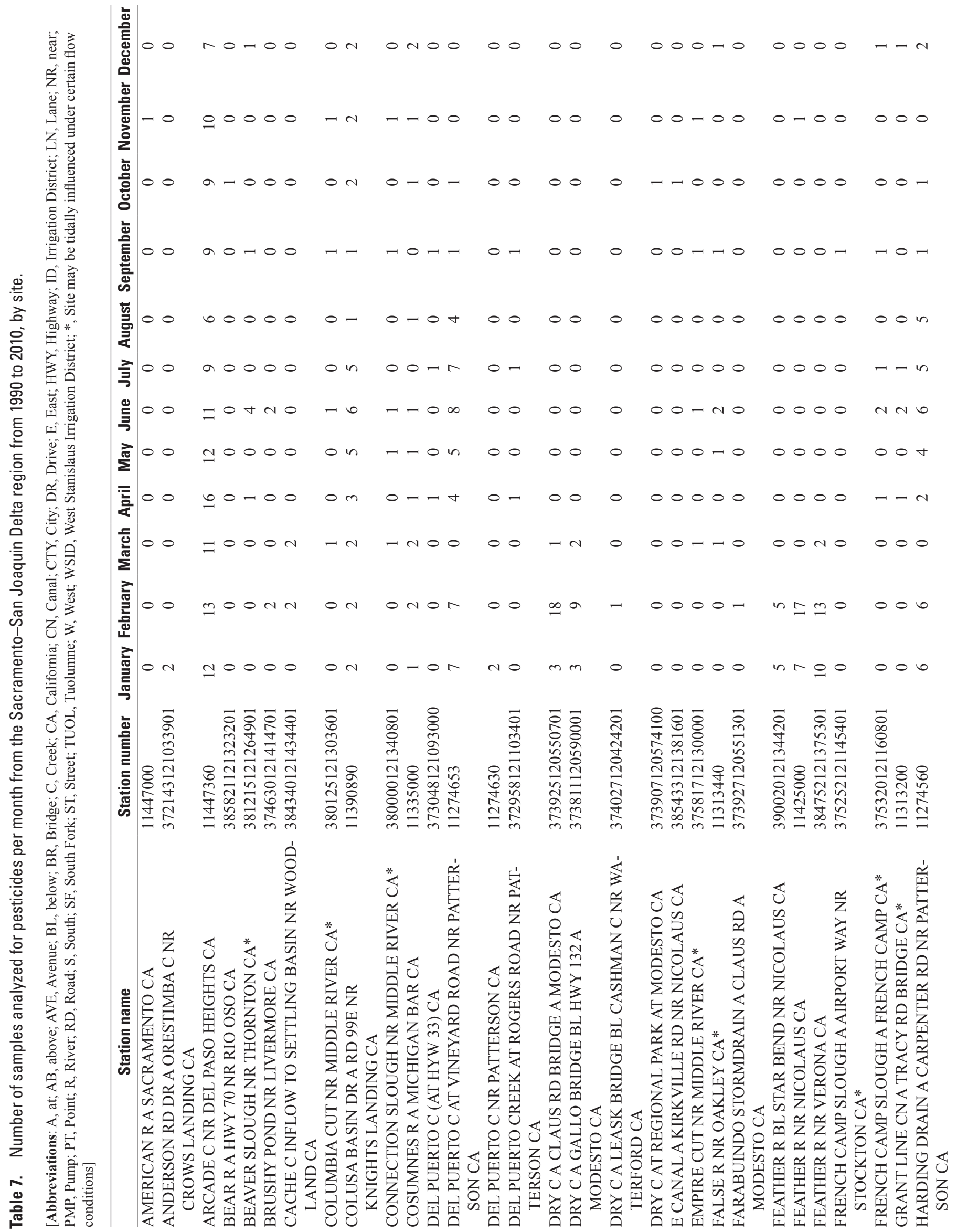




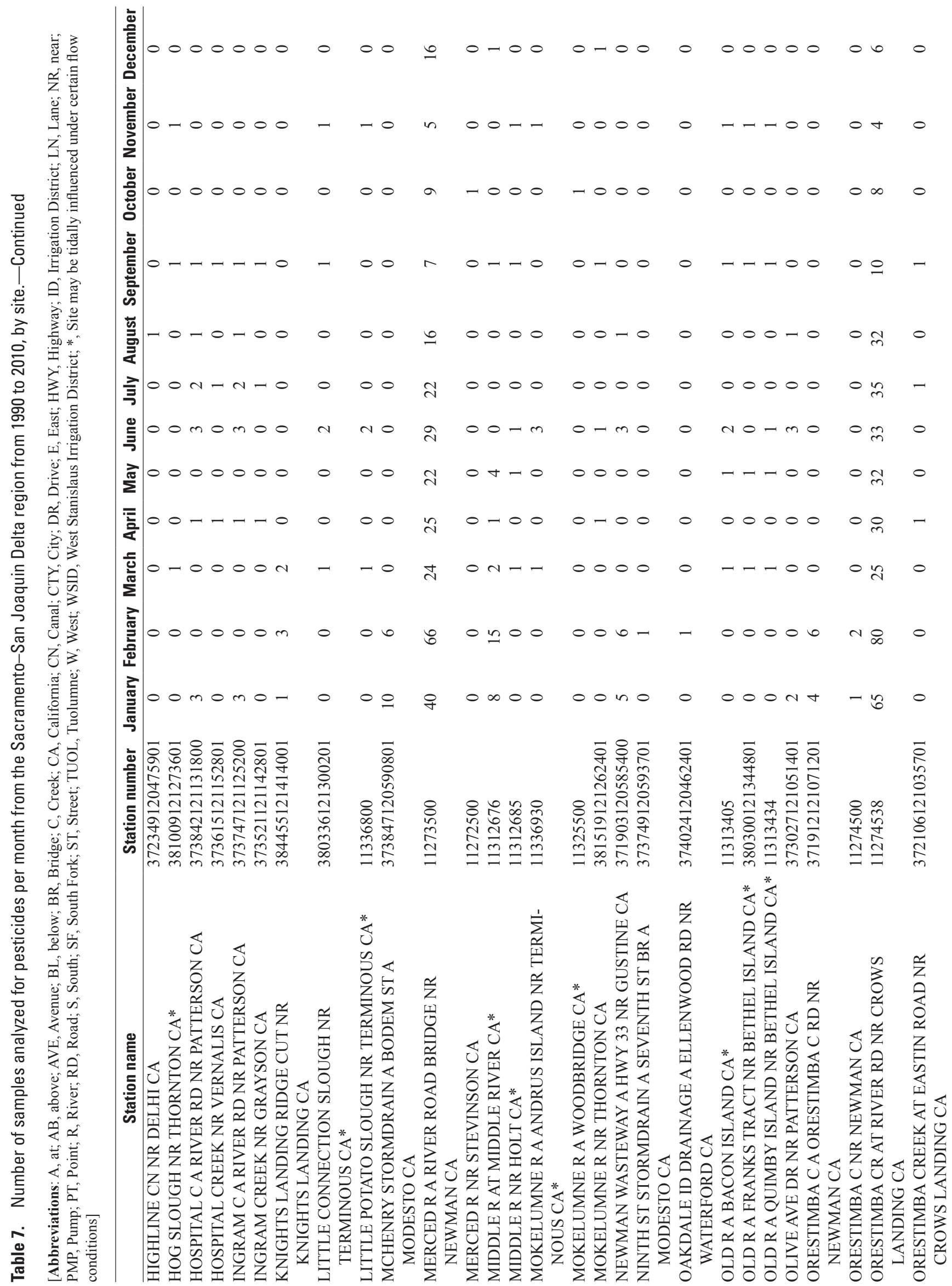




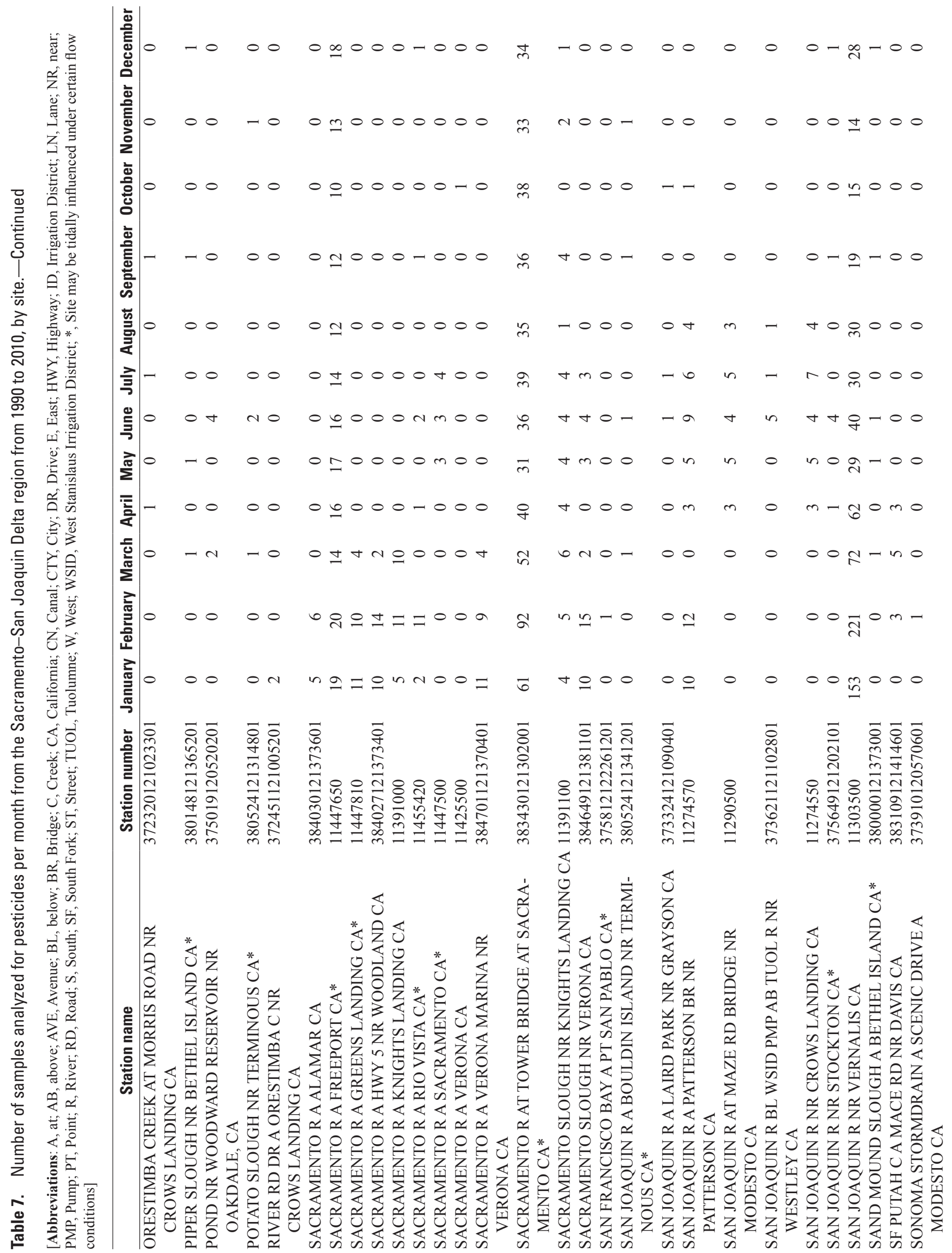




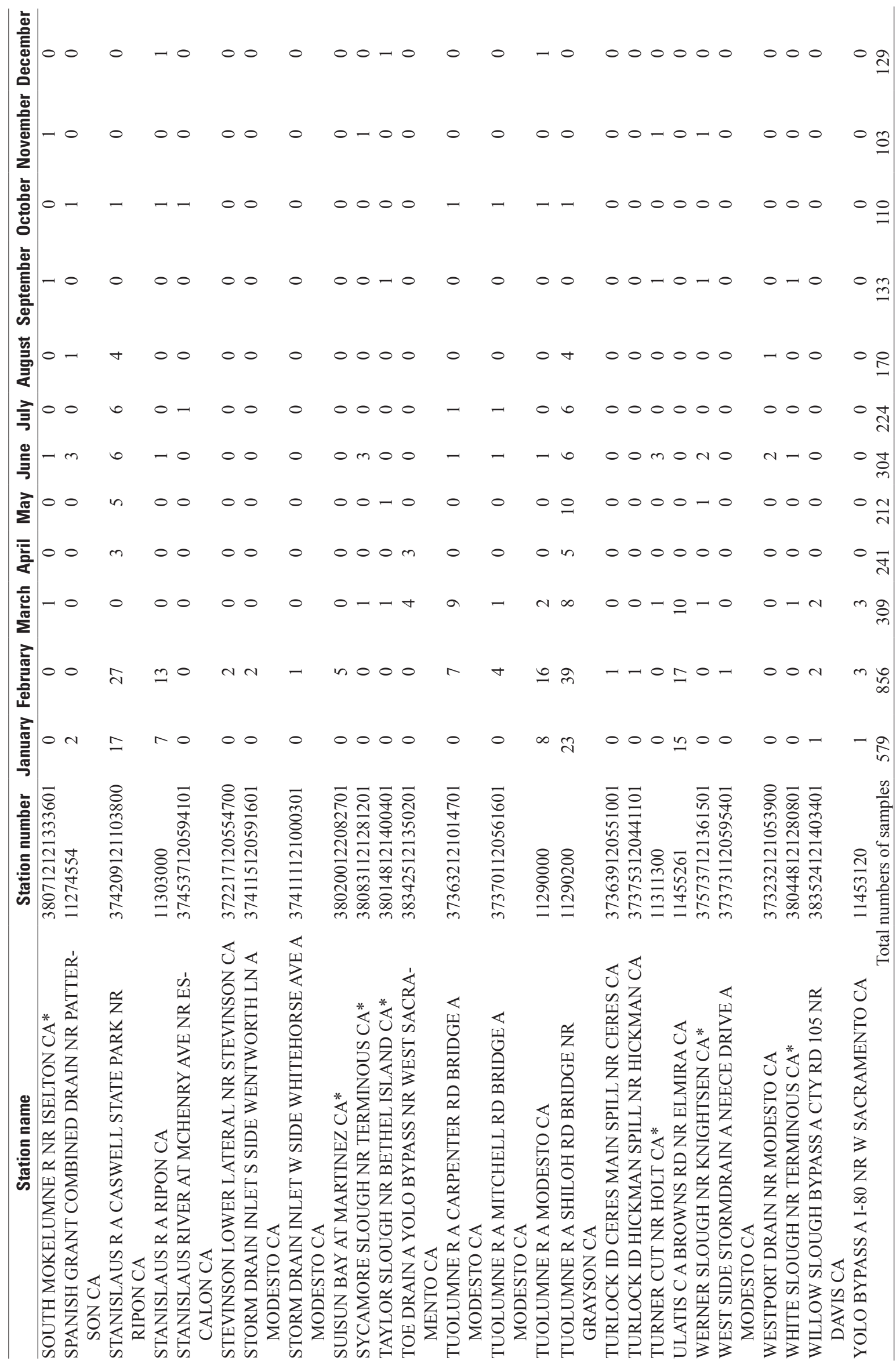




\section{Appendix}




\section{Appendix 1. U.S. Geological Survey Pesticide Concentration Data for Environmental Water and Sediment Samples Collected at Surface-Water Sampling Sites in the Sacramento-San Joaquin Delta Region 1990-2010.}

Appendix table provided as a separate Microsoft ${ }^{\circledR}$ Excel file. 


\section{Appendix 2. U.S. Geological Survey Pesticide Concentration Data for Quality-Control Water and Sediment Samples Collected at Surface-Water Sampling Sites in the Sacramento-San Joaquin Delta Region 1990-2010.}

Appendix table provided as a separate Microsoft ${ }^{\circledR}$ Excel file. 
Appendix 3. References for Analytical Methods Applicable to Data Presented in Appendices 1 and 2. 
Appendix 3. References for analytical methods applicable to data presented in appendices 1 and 2.

\section{Report reference}

Crepeau, K.L., Domagalski, J.L., and Kuivila, K.M., 1994, Methods of analysis and quality-assurance practices of the U.S. Geological Survey Organic Laboratory, Sacramento, California-Determination of pesticides in water by solid-phase extraction and capillary-column gas chromatography/mass spectrometry: U.S. Geological Survey Open-File Report 94-362, 17 p.

Fishman, M.J., 1993, Methods of analysis by the U.S. Geological Survey National Water Quality Laboratory-Determination of inorganic and organic constituents in water and fluvial sediments: U.S. Geological Survey Open-File Report 93-125.

Foreman, W.T., Connor, B.F., Furlong, E.T., Vaught, D.G., and Merten, L.M., 1995, Methods of analysis by the U.S. Geological Survey National Water Quality Laboratory-Determination of organochlorine pesticides and polychlorinated biphenyls in bottom sediment by dual capillary-column gas chromatography with electron-capture detection: U.S. Geological Survey Open-File Report 94-351.

Furlong, E.T., Anderson, B.D., Werner, S.L., Soliven, P.P., Coffey, L.J., and Burkhardt, M.R., 2001, Methods of analysis by the U.S. Geological Survey National Water Quality Laboratory_Determination of pesticides in water by graphitized carbon-based solid-phase extraction and high-performance liquid chromatography/mass spectometry: U.S. Geological Survey Water-Resources Investigations Report 01-4134.

Hladik, M.L., Smalling, K.L., and Kuivila, K.M., 2008, A multi-residue method for the analysis of pesticides and pesticide degradates in water using Oasis HLB solid phase extraction and gas chromatography-ion trap mass spectrometry: Bulletin of Environmental Contamination and Toxicology, v. 80, p. 139-144.

Jha, V.K., and Wydoski, D.S., 2002, Methods of analysis of the U.S. Geological Survey National Water Quality Laboratory-Determination of organophosphate pesticides in filtered water by gas chromatography with flame photometric detection: U.S. Geological Survey WaterResources Investigations Report 02-4071, 37 p.

Jha, V.K., and Wydoski, D.S., 2003, Methods of analysis of the U.S. Geological Survey National Water Quality Laboratory-Determination of organophosphate pesticides in bottom sediment by gas chromatography with flame photometric detection: U.S. Geological Survey WaterResources Investigations Report 02-4222, 38 p.

Jha, V.K., and Wydoski, D.S., 2003, Methods of analysis of the U.S. Geological Survey National Water Quality Laboratory-Determination of organophosphate pesticides in whole water by continuous liquid-liquid extraction and capillary-column gas chromatography with flame photometric detection: U.S. Geological Survey Water-Resources Investigations Report 03-4139, 34 p.

Madsen, J.E., Sandstrom, M.W., and Zaugg, S.D., 2003, Methods of analysis of the U.S. Geological Survey National Water Quality Laboratory-A method supplement for the determination of fipronil and degradates in water by gas chromatography/mass spectrometry: U.S. Geological Survey Open-File Report 02-462, 16 p.

Markovchick, D.J., Lewis, J.A., Brenton, R.W., Iverson, J.L., and Wharry, H.L., 1994, Methods of analysis by the U.S. Geological Survey National Water Quality Laboratory_-Determination of triazine and other nitrogen-containing compounds by gas chromatography with nitrogen phosphorous detectors: U.S. Geological Survey Open-File Report 94-037.

Meyer, M.T., Loftin, K.A., Lee, E.A., Hinshaw, G.H., Dietze, and J.E., Scribner, E.A., 2009, Determination of glyphosate, its degradation product aminomethylphosphonic acid, and glufosinate, in water by isotope dilution and online solid-phase extraction and liquid chromatography/tandem mass spectrometry: U.S. Geological Survey Techniques and Methods, book 5, chap. A10, 32p.

Noriega, M.C., Wydoski, D.S., and Foreman, W.T., 2004, Methods of analysis of the U.S. Geological Survey National Water Quality Laboratory-Determination of organochlorine pesticides and polychlorinated biphenyls in bottom and suspended sediment by gas chromatography with electron-capture detection: U.S. Geological Survey Water-Resources Investigations Report 03-4293, 54 p.

Sandstrom, M.W., Stroppel, M.E., Foreman, W.T., and Schroeder, M.P., 2001, Methods of analysis by the U.S. Geological Survey National Water Quality Laboratory-Determination of moderate-use pesticides and selected degradates in water by C-18 solid-phase extraction and gas chromatography/mass spectrometry: U.S. Geological Survey Water-Resources Investigations Report 01-4098, 70 p.

Smalling, K.L., and Kuivila, K.M., 2008, Multi-residue method for the analysis of 85 current-use and legacy pesticides in bed and suspended sediments: Journal of Chromatography A, v. 1210, p. 8-18.

Werner, S.L., Burkhardt, M.R., and DeRusseau, S.N., 1996, Methods of analysis by the U.S. Geological Survey National Water Quality Laboratory-Determination of pesticides in water by Carbopak-B solid-phase extraction and high-performance liquid chromatography: U.S. Geological Survey Open-File Report 96-216.

Zaugg, S.D., Sandstrom, M.W., Smith, S.G., and Fehlberg, K.M., 1995, Methods of analysis by the U.S. Geological Survey National Water Quality Laboratory-Determination of pesticides in water by C-18 solid-phase extraction and capillary-column gas chromatography/mass spectrometry with selected-ion monitoring: U.S. Geological Survey Open-File Report 95-181. 
Prepared by the Sacramento Publishing Service Center.

For more information concerning this report, contact:

Director

U.S. Geological Survey

California Water Science Center

6000 J Street, Placer Hall

Sacramento, CA 95819

(916) 278-3000

or visit our Web site at:

http://ca.water.usgs.gov 
